\title{
Ionic Currents Underlying Developmental Regulation of Repetitive Firing in Aplysia Bag Cell Neurons
}

\author{
Teresa A. Nick, ${ }^{1}$ Leonard K. Kaczmarek, ${ }^{1,3}$ and Thomas J. Carew ${ }^{1,2}$ \\ 1/nterdepartmental Neuroscience Program, 2Departments of Psychology and Biology, Yale University, New Haven, \\ Connecticut 06510, and ${ }^{3}$ Departments of Pharmacology and Cellular and Molecular Physiology, Yale University School of \\ Medicine, New Haven, Connecticut 06510
}

We have investigated the developmental regulation of the ability to fire repetitively in the bag cell neurons of Aplysia californica, a neuronal system in which the behavioral effects of repetitive firing are well characterized. Adult bag cell neurons exhibit an afterdischarge, consisting of prolonged depolarization and repetitive firing, which causes the release of several peptides from these neurons that induce egg-laying behaviors. Afterdischarge can be triggered in vitro by a variety of stimuli, including electrical stimulation and exposure to the potassium channel blocker tetraethyl ammonium chloride (TEA). In contrast to adults, juvenile neurons did not exhibit afterdischarge in response to pleural-abdominal connective shock or TEA. Juvenile neurons did exhibit, however, prolonged depolarizations in the presence of TEA, perhaps reflecting the anlage of the mechanism responsible for afterdischarge in the adult.

To investigate developmental mechanisms underlying the regulation of repetitive firing, we compared ionic currents in adult and juvenile bag cell neurons. We found that during the period in which these neurons acquire the capacity to fire repetitively, a number of currents are regulated: (1) three $\mathrm{K}^{+}$ currents decrease $\left(\mathrm{Ca}^{2+}\right.$-dependent $\mathrm{K}^{+}$and two components of voltage-dependent delayed-rectifier $\mathrm{K}^{+}$current); (2) A-type $\mathrm{K}^{+}$current increases; and (3) two $\mathrm{Ca}^{2+}$ currents increase (basal and PKC-activated). This pattern is consistent with the increase in the ability to fire repetitively that we observe during maturation: our results indicate that developmental control of repetitive firing in this system is accompanied by selective regulation of specific ionic currents which, after maturation, play important roles in generating the afterdischarge and triggering egg-laying behaviors.

Key words: ion channel; bag cell neurons; Aplysia; development; neuroendocrine; delayed rectifier; potassium current; calcium current; culture; bursting; voltage clamp
Selective developmental expression of voltage-gated ion channels controls the maturation of electrical excitability in many types of neurons (for review, see Spitzer, 1991; Ribera and Spitzer, 1992). Although the precise sequence of expression of ionic currents has been described for several neuronal types, the ontogeny of currents in neurons that are capable of prolonged trains of action potentials is not well understood. Thus, in the present paper, we examined the developmental regulation of ion currents in repetitively firing bag cell neurons that are required for the maturation of reproduction in Aplysia californica.

The bag cell neurons provide several advantages as a system in which to investigate developmental regulation of ionic currents underlying a form of repetitive firing that has a clear role in behavior: (1) the adult form of excitability, afterdischarge, is well characterized (for review, see Conn and Kaczmarek, 1989); (2) these neurons are easily identified, even in young animals; and (3) the functional significance of the afterdischarge is well understood. Specifically, bag

Received May 24, 1996; revised Sept. 9, 1996; accepted Sept. 9, 1996.

This work was supported by U.S. Public Health Service Grant 1 F31 MH10914-01 (T.A.N.), National Science Foundation Grant BNS 8614961 (T.J.C.), and National Institutes of Health Grant NS 18492 (L.K.K.). This work was completed as part of a doctoral thesis for Yale University (T.A.N.). We gratefully acknowledge Angeles Ribera for reviewing a preliminary draft of this manuscript and providing insightful comments and suggestions. We also greatly appreciate the advice of Lesley Blair, Haig Keshishian, and Fred Sigworth throughout the progress of this study.

Correspondence should be addressed to Thomas J. Carew, Department of Psychology, Yale University, P.O. Box 208205, New Haven, CT 06520-8205.

Teresa Nick's current address: University of Colorado Health Sciences Center, Department of Physiology, Campus Box C240, 4200 East Ninth Avenue, Denver, CO 80262.

Copyright (C) 1996 Society for Neuroscience $0270-6474 / 96 / 167583-16 \$ 05.00 / 0$ cell neuron afterdischarge has an essential, well characterized role in the reproduction of Aplysia: it triggers the release of several bioactive peptides, which act on a variety of neural and non-neural targets (Branton et al., 1978a,b; Dudek and Tobe, 1978; Stuart and Strumwasser, 1980) and stimulate egg-laying behaviors (Kupfermann, 1967; Pinsker and Dudek, 1977; Dudek et al., 1979; Mackey and Carew, 1983). Thus, the bag cell neurons are an excellent model system for investigation of the developmental acquisition of repetitive firing capacity in the larger context of the functional analysis of neural circuits and behavior.

We have identified a period in Aplysia development when the bag cell neurons are easily recognized and accessible for cellular analysis. Moreover, at this time they are capable of secreting peptide hormone in response to a depolarizing stimulus, but are not yet electrophysiologically mature (Nick et al., 1996). Specifically, juvenile neurons do not show the adult form of excitability, afterdischarge, which is a period of prolonged (10-60 $\mathrm{min}$ ) depolarization and repetitive firing (Kupfermann and Kandel, 1970) (for review, see Conn and Kaczmarek, 1989). Using the juvenile period of development as a starting point, we systematically explored the changes in ionic currents expressed by these neurons as they acquire the capacity for afterdischarge. We found that, during the period that bag cell neurons become capable of repetitive firing, a number of specific current densities are selectively regulated: (1) three potassium currents decrease; (2) one potassium current increases; and (3) two calcium currents increase. The overall developmental expression pattern of ion currents is consistent with the increase in electrical excitability that we observed during development. 


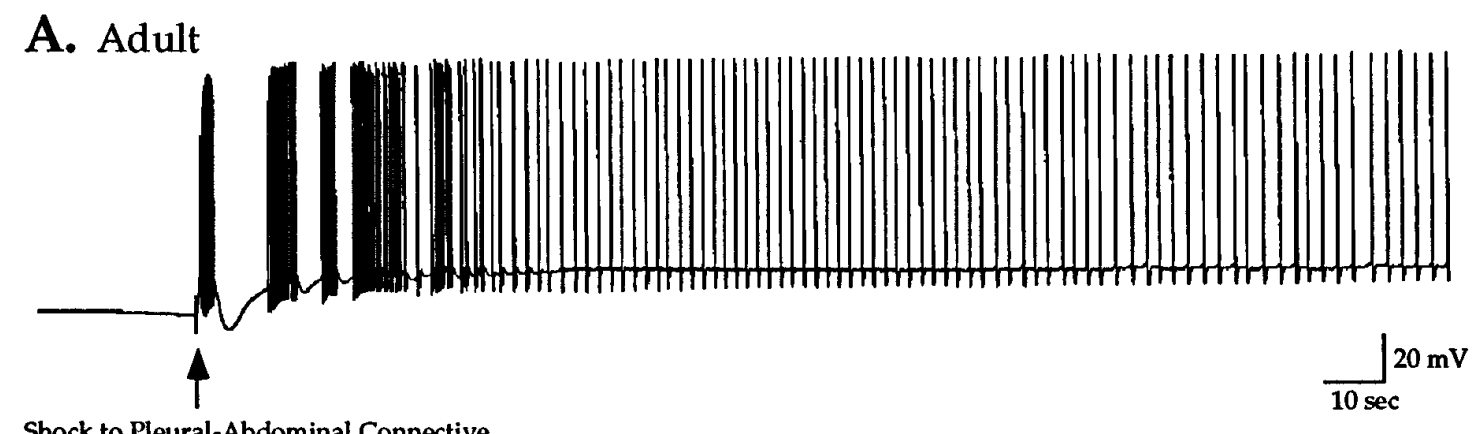

Shock to Pleural-Abdominal Connective

\section{B. Juvenile}
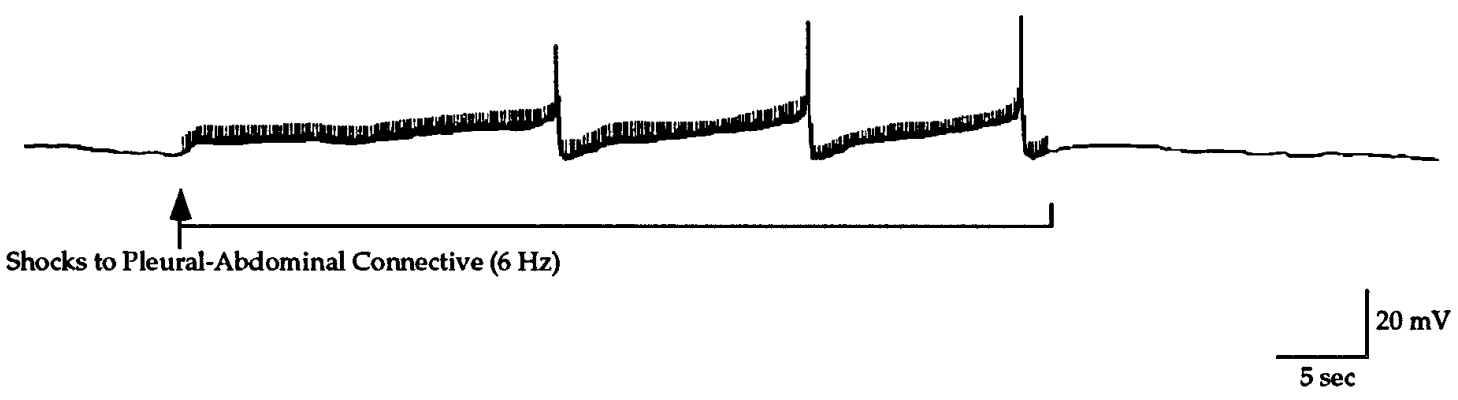

Figure 1. Unlike adult cells, juvenile bag cell neurons do not afterdischarge in response to pleural-abdominal connective shock. Intracellular records from bag cell neurons in intact abdominal ganglia reveal clear differences between excitability in adult $(A)$ and juvenile $(B)$ bag cell neurons. Each small upward voltage deflection in $B$ is a stimulus artifact from a shock to the pleural-abdominal connective. Juvenile bag cell neurons show small ( $\sim 2 \mathrm{mV})$ depolarizations in response to connective shock that occasionally summate to trigger single action potentials.

Aspects of this work have appeared previously in abstract form (Nick et al., 1993, 1995).

\section{MATERIALS AND METHODS}

\section{Animals}

Wild-caught Aplysia californica weighing 53.8-241.2 gm were obtained from Marinus Inc. (Long Beach, CA). Cultured $A$. californica weighing 2.1-77.9 gm were obtained from the Aplysia Resource Facility (RSMAS, University of Miami, Miami, FL). The age of laboratory cultured Aplysia weighing $2.1-50 \mathrm{gm}$ was $106-155 \mathrm{~d}$ post-hatching. Animals were maintained in aquaria containing continuously circulating, aerated Instant Ocean (Aquarium Systems, Mentor, $\mathrm{OH}$ ) at $15^{\circ} \mathrm{C}$. Aplysia weighing $>50$ $\mathrm{gm}$ were fed twice weekly with dried seaweed. Animals weighing $<50 \mathrm{gm}$ were given access ad libitum to laboratory-grown macroalgae from the Aplysia Resource Facility.

\section{Intact ganglia}

Animals were anesthetized by injection of isotonic $\mathrm{MgCl}_{2}$ (50\% body weight) into the body cavity. The abdominal ganglion, together with the pleural-abdominal connectives, was dissected and placed in collagenase Type IV [250 U/ml artificial seawater (ASW); Sigma, St. Louis, MO)] for $30 \mathrm{~min}$ at $15^{\circ} \mathrm{C}$. The ganglion was then pinned in a SYLGARD-coated (Dow Corning, Midland, MI) Petri dish in circulating ASW (460 mm $\mathrm{NaCl}, 55 \mathrm{~mm} \mathrm{MgCl}_{2}, 11 \mathrm{~mm} \mathrm{CaCl}_{2}, 10 \mathrm{~mm} \mathrm{KCl}, 10 \mathrm{~mm}$ Trizma, $\mathrm{pH}$ 7.6), which was chilled with ice to $\sim 17^{\circ} \mathrm{C}$. In low-calcium ASW, $2 \mathrm{~mm} \mathrm{CaCl}{ }_{2}$ was substituted for $11 \mathrm{~mm} \mathrm{CaCl}$. Both connectives were drawn into suction electrodes, and action potentials were recorded extracellularly for at least $5 \mathrm{~min}$ to ensure preparation stability. Intracellular records were obtained using $\sim 15 \mathrm{M} \Omega$ glass microelectrodes filled with $3 \mathrm{M} \mathrm{KCl}$, which were used to penetrate the connective tissue sheath and record transmembrane bag cell neuron activity.

After microelectrode penetration of either one or two bag cell neurons, one or both connectives were stimulated $(40 \mathrm{~V}, 2.5 \mathrm{msec}$ pulses at $6 \mathrm{~Hz}$ for $10 \mathrm{sec}$ ). Occurrence of afterdischarge (an $\sim 20 \mathrm{~min}$ period of pro- longed depolarization and repetitive firing; Kupfermann and Kandel, 1970; Conn and Kaczmarek, 1989) in response to connective stimulation in the bag cell neuron(s) recorded was noted. If the neuron did not afterdischarge in response to connective stimulation, $75 \mathrm{~mm}$ tetraethyl ammonium chloride (TEA; Sigma) was washed through the bath. TEA triggers afterdischarge in adult bag cell clusters (Kaczmarek et al., 1982). Again, one or both connectives were stimulated, and occurrence of afterdischarge or other activity was recorded. To examine the calcium sensitivity of action potential height and of the duration of juvenile TEA-induced prolonged depolarizations (described below), extracellular calcium concentration was lowered to $2 \mathrm{~mm}$ after at least $5 \mathrm{~min}$ of exposure to TEA and subsequently washed out. We also investigated the calcium dependence of duration of depolarization with TEA-containing ASW that had $2 \mathrm{mM} \mathrm{CaCl}_{2}$ and $9 \mathrm{mM} \mathrm{BaCl}_{2}$ substituted for $11 \mathrm{mM} \mathrm{CaCl}_{2}$. The duration of depolarization increases with time in TEA (see below). In an effort to study calcium sensitivity without the complicating effects of TEA on duration of depolarization, we averaged control duration and peak voltage values for all depolarizations that occurred in $11 \mathrm{~mm}$ calcium during the $5 \mathrm{~min}$ period before the solution was changed to $2 \mathrm{~mm}$ calcium and during the 5 min recovery period after the solution was changed back to $11 \mathrm{~mm}$ calcium. We compared these control values to those from the $10 \mathrm{~min}, 2 \mathrm{~mm}$ calcium period.

Action potentials were recorded extracellularly through suction electrodes and amplified using a Grass P5 Series Pre-Amplifier (Quincy, MA). Action potentials and prolonged depolarizations were also recorded intracellularly through glass microelectrodes and amplified using a Getting 5A amplifier (Iowa City, IA). Signals were monitored with a Tektronix 5111A oscilloscope (Lexington, MA) and stored on reel-to-reel tapes using a Vetter Model D1 Instrumentation Recorder (Rebersburg, PA) and on chart paper using a Gould chart recorder (Valley View, OH).

\section{Isolated neurons}

Animals were anesthetized as described above. For the "juvenile" group, only Aplysia weighing $<11$ gm were included. For the "adult" group, only animals weighing $>100$ gm were used. The abdominal ganglion, together 


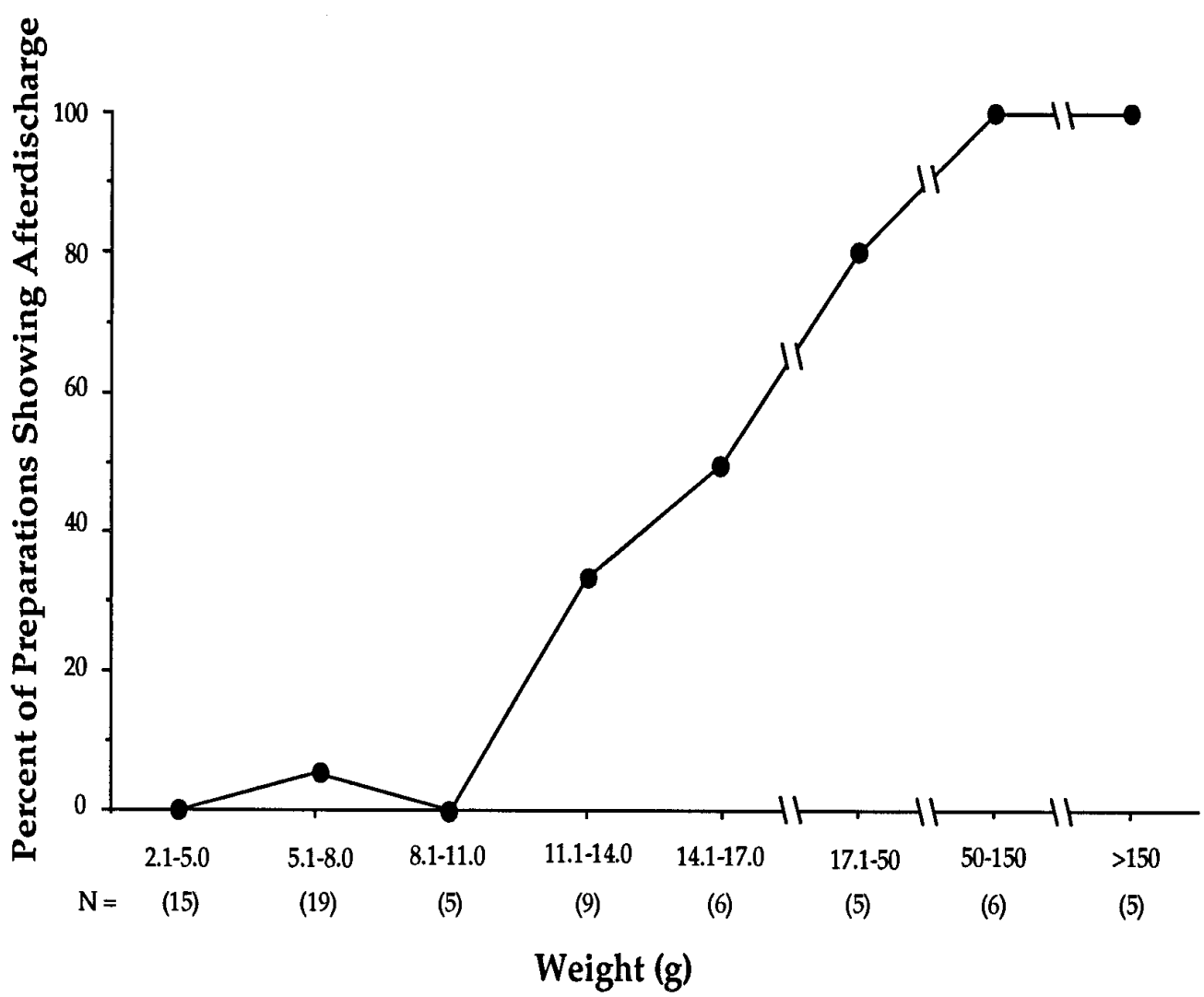

Figure 2. Capacity for afterdischarge increases during juvenile development. Only 1 of 39 preparations from Aplysia weighing $<11$ gm afterdischarged, whereas all preparations from animals weighing $>50 \mathrm{gm}$ afterdischarged. There is a clear transition period between 11 and $50 \mathrm{gm}$ during which the percent of preparations that afterdischarge progressively increases.

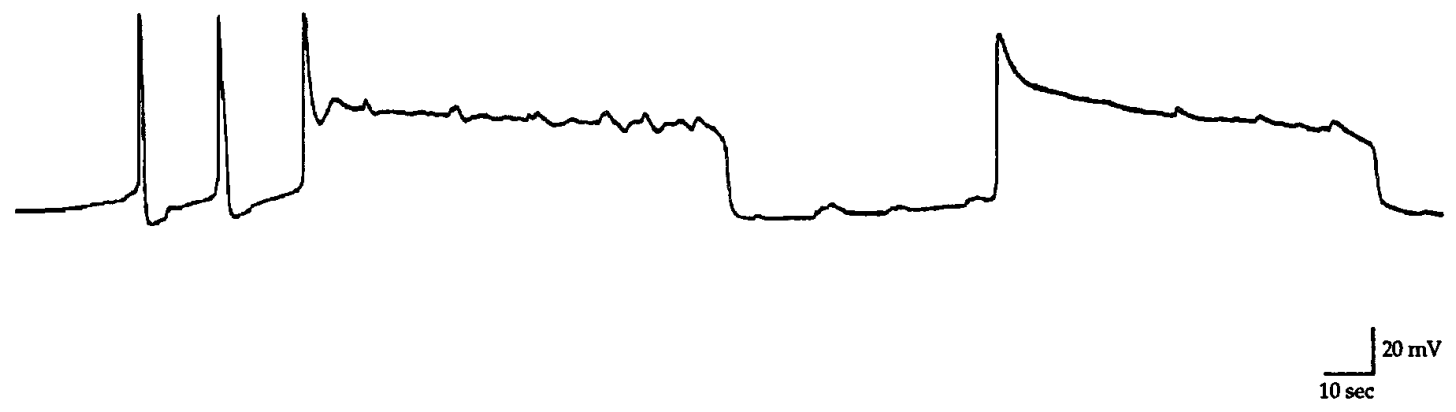

Figure 3. Juvenile bag cell neurons that do not afterdischarge nonetheless exhibit prolonged depolarizations in the presence of the potassium channel blocker TEA. TEA $(75 \mathrm{mM})$ was washed into the bath $\sim 5 \mathrm{~min}$ before the beginning of this record. The last two spikes are followed by a prolonged plateau at -5 to $-15 \mathrm{mV}$. For quantitative group results, see text.

with the pleural-abdominal connectives, was dissected and placed in Dispase protease $(40 \mathrm{mg} / 3 \mathrm{ml}$; Boehringer Mannheim, Mannheim, Germany) for $\sim 18 \mathrm{hr}$. Bag cell neurons were dissociated and plated in ASW for neuron culture (cASW; $460 \mathrm{~mm} \mathrm{NaCl}, 10.4 \mathrm{~mm} \mathrm{KCl}, 55 \mathrm{~mm} \mathrm{MgCl} 2,11$ $\mathrm{mM} \mathrm{CaCl}_{2}, 15 \mathrm{~mm}$ HEPES, $1 \mathrm{gm} / \mathrm{l}$ glucose, $100,000 \mathrm{U} / \mathrm{l}$ penicillin, $100 \mathrm{mg} / \mathrm{l}$ streptomycin, $\mathrm{pH} 7.8$ ) on Corning $35 \times 10 \mathrm{~mm}$ polystyrene tissue culture dishes. After $18-26 \mathrm{hr}$ at $15^{\circ} \mathrm{C}$, current- and voltage-clamp recordings of the neurons were made using the whole-cell patch-clamp technique (Hamill et al., 1981) at room temperature $\left(\sim 22^{\circ} \mathrm{C}\right)$. To ensure viability, neurons selected for recording had neurites that were at least one-half the soma diameter. Neurons with very long neurites ( $>2$ soma diameters) were excluded to allow sufficient voltage clamp of the entire surface membrane. Resistance of electrodes was $\leq 1.5 \mathrm{M} \Omega$. The current signal was balanced to zero with the pipette immersed in the bathing solution. A 486DX computer (Zenith Data Systems) with a Digidata 1200 A/D converter (Axon Instruments, Foster City, CA) was used to deliver current pulses in current-clamp and voltage steps in voltage clamp using pClamp 6 software (Axon Instruments).
Cells were visualized with a Zeiss IM-35 inverted microscope (Thornwood, NY). Whole-cell electrical signals were amplified using an EPC-7b patch/whole-cell clamp (List-Electronic), displayed on a Tektronix T511A oscilloscope, and stored on VCR tapes using an A/D VCR adaptor (Medical Systems Corp., Greenvale, NY) and on computer disk using pClamp 6 software on a Zenith Data Systems 486 computer. The EPC7 b's 0.5 G $\Omega$ feedback resistor was used for measurement of all currents except juvenile calcium currents, for which a $50 \mathrm{G} \Omega$ resistor was used. Calcium currents were filtered at $3 \mathrm{kHz}$ with an 8-pole Bessel filter built into the EPC-7b amplifier and sampled at $600 \mathrm{~Hz}$. Potassium currents were filtered at $5 \mathrm{kHz}$ and sampled at $1 \mathrm{kHz}$. Durations of voltage steps for measuring currents were $300 \mathrm{msec}$, except for measuring the transient inactivating potassium current $\left(I_{\mathrm{KA}} ; 500 \mathrm{msec}\right)$ and for measuring capacitance $(120 \mathrm{msec})$. Series resistance and capacitance transients were compensated before ionic current measurement. Currents were leaksubtracted using a $\mathrm{P} / 8$ protocol.

Current-clamp recordings were made using Standard pipette solution (see below). While holding the neuron at $-40 \mathrm{mV}$ with injected current, 
Figure 4. Extracellular calcium modulates the initial spike amplitude and the duration of TEA-induced prolonged depolarization. Artificial seawater normally contains $11 \mathrm{~mm}$ calcium. When the calcium concentration is lowered to $2 \mathrm{mM}$, the prolonged depolarizations induced by $75 \mathrm{~mm}$ TEA exhibit two changes: (1) decreased amplitude of the initial spike, and (2) increased duration of depolarization. Addition of barium to preserve the concentration of divalent cations does not affect the duration of depolarization. For quantitative group results, see text.

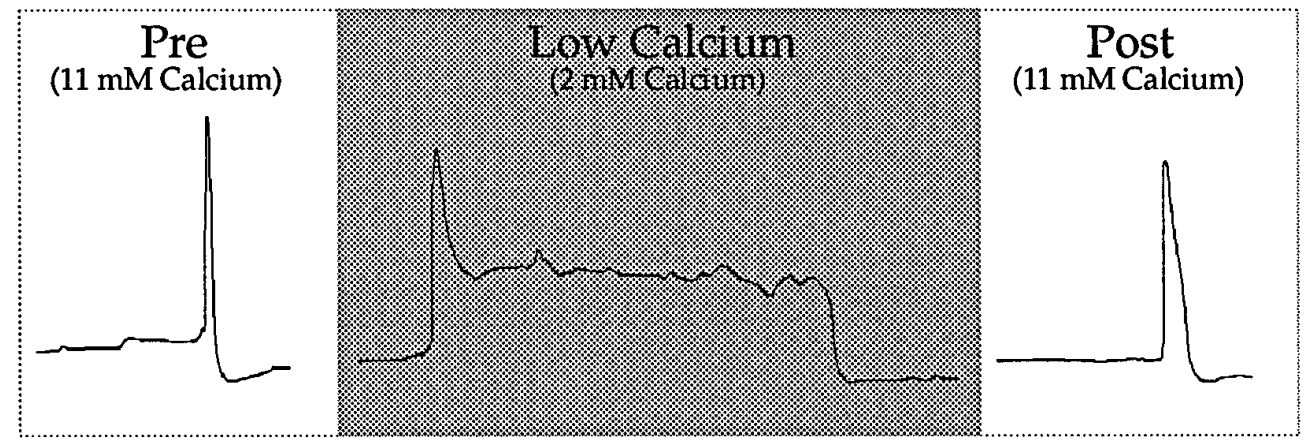

$20 \mathrm{mV}$
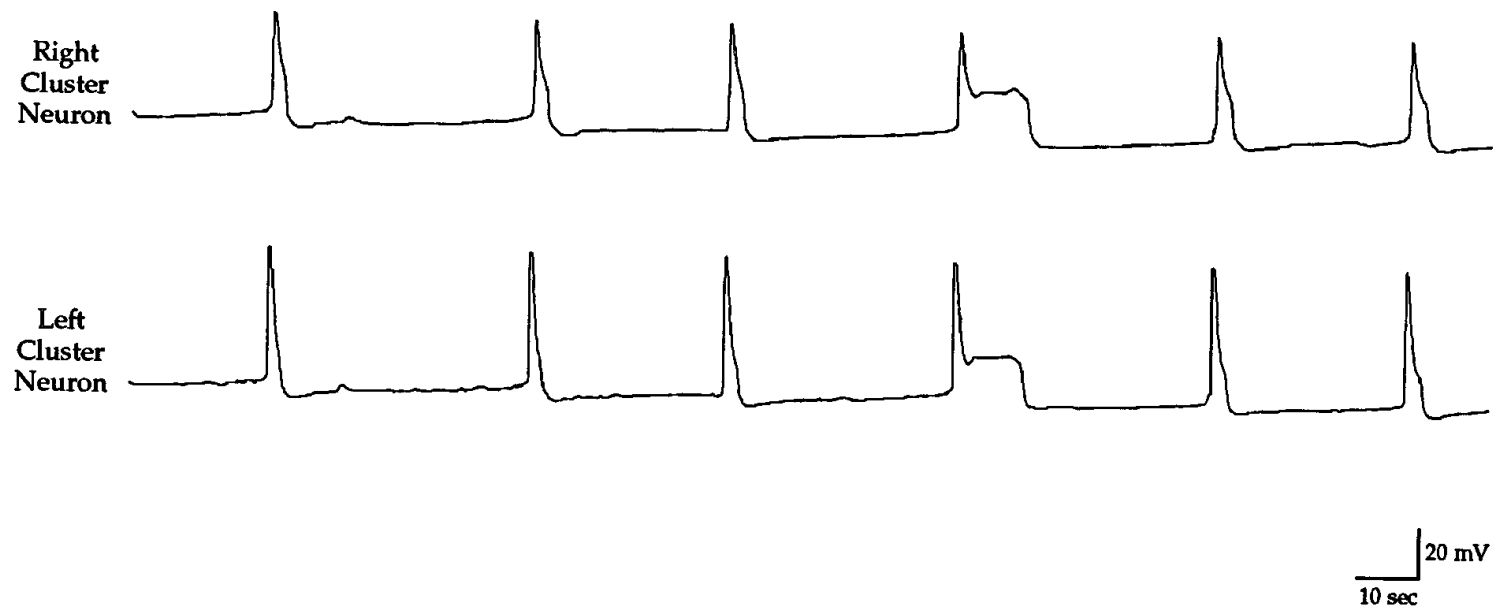

Figure 5. TEA-triggered prolonged depolarizations in juvenile bag cell neurons occur synchronously in both bag cell clusters. Simultaneous microelectrode recording of bag cell neurons in opposite clusters reveals that the prolonged depolarizations induced by 75 mM TEA occur coincidentally in both clusters.

a $500 \mathrm{msec}$ current pulse that could trigger at least one spike $(0.1 \mathrm{nA}$ for juvenile; $0.5 \mathrm{nA}$ for adult) was given. Larger current injections did not yield more spikes in juvenile neurons. The number of spikes in response to the current pulse and the most negative voltage achieved during afterhyperpolarization (AHP) were analyzed. To be counted, minimum spike amplitude needed to be $30 \mathrm{mV}$.

All currents were normalized for cell size by dividing by the membrane capacitance, which gives the current density (in $\mathrm{nA} / \mathrm{nF}$ ). Membrane capacitance was measured as follows. (1) Neurons were held at $-40 \mathrm{mV}$ and stepped to $-90 \mathrm{mV}$ in five $10 \mathrm{mV}, 120 \mathrm{msec}$ steps. (2) To remove contamination of the measurement caused by leak current, the current baseline was adjusted post hoc such that the average of the last $50 \mathrm{msec}$ of the step was set to zero. (3) The area of each capacitative transient (charge; $\mathrm{nA} \cdot \mathrm{msec}$ ) was measured from 0 to $50 \mathrm{msec}$ after the initiation of the voltage step. (4) These areas were plotted relative to voltage. (5) These charge-voltage curves were then fitted using linear regression. (6) The slope of the linear regression gave the membrane capacitance.

Measurement of outward currents. The voltage-gated outward current of bag cell neurons is made up of at least four potassium currents: A-type potassium current $\left(I_{\mathrm{KA}}\right)$; noninactivating delayed-rectifier $\left(I_{\mathrm{KV} 1}\right)$; inactivating delayed-rectifier $\left(I_{\mathrm{KV} 2}\right)$; and calcium-dependent potassium current $\left(I_{\mathrm{KCa}}\right)$. Non-calcium-sensitive potassium currents were observed using a pipette solution that contained the calcium chelator BAPTA: $570 \mathrm{~mm}$ potassium aspartate, $10 \mathrm{~mm}$ HEPES, $10 \mathrm{~mm}$ reduced glutathione, $5 \mathrm{~mm}$ $\mathrm{MgCl}_{2}, 1 \mathrm{mg} / \mathrm{ml}$ glucose, $10 \mathrm{~mm}$ BAPTA, $5 \mathrm{~mm}$ ATP, $0.1 \mathrm{~mm}$ GTP, $\mathrm{pH}$ 7.3. BAPTA was used to remove $I_{\mathrm{KCa}}$. To ensure that differences seen between adult and juvenile neurons were not caused by incomplete dialysis of neurons with BAPTA, in 8 of 14 juvenile bag cell neurons and in 5 of 9 adult neurons, membrane-permeable $25 \mu \mathrm{M}$ BAPTA-AM was also added to the static bath 30-60 min before recording. Because these ionic current values were not different from those from cells that had only been exposed to BAPTA from the pipette, all values were combined. External solution was cASW.

$I_{\mathrm{KA}}$ was analyzed by holding at $-80 \mathrm{mV}$ and stepping to $-20 \mathrm{mV}$ in three $20 \mathrm{mV}$ steps with a $10 \mathrm{sec}$ interpulse interval. $I_{\mathrm{KV} 1}$ was revealed using a TRAIN protocol to remove inactivating components of delayedrectifier (see Fig. $7 B$ ): 10 prepulses $(100 \mathrm{msec} ;+70 \mathrm{mV} ; 1 \mathrm{~Hz}$ while holding at $-40 \mathrm{mV}$ ) preceded each of 9 test pulses from -40 to $+120 \mathrm{mV}$ in $20 \mathrm{mV}$ steps. $I_{\mathrm{KCa}}$ was inferred by subtracting values obtained using the TRAIN protocol with $10 \mathrm{~mm}$ BAPTA pipette solution from those obtained from cells in the same Petri dish with Standard pipette solution, which contained $0.2 \mathrm{~mm}$ EGTA substituted for $10 \mathrm{~mm}$ BAPTA. Juvenile neurons died when the pipette was withdrawn. Thus, different populations of both adult and juvenile cells were used for measurements in Standard and BAPTA solution. Thus, $I_{\mathrm{KCa}}$ could only be estimated. Total delayed-rectifier current was revealed with the 30SEC protocol, which was the same as the TRAIN protocol, without prepulses and with a $30 \mathrm{sec}$ recovery period between each test pulse (see Fig. $7 A$ ). Subtraction of the traces acquired with the TRAIN protocol $\left(I_{\mathrm{KV} 1}\right)$ from those acquired with the $30 \mathrm{SEC}$ protocol (total delayed-rectifier) revealed $I_{\mathrm{KV} 2}$ (see Fig. 7).

Measurement of inward currents. Calcium currents were studied using a pipette solution that blocked outward currents: $10 \mathrm{mM}$ HEPES, $10 \mathrm{~mm}$ 
A.

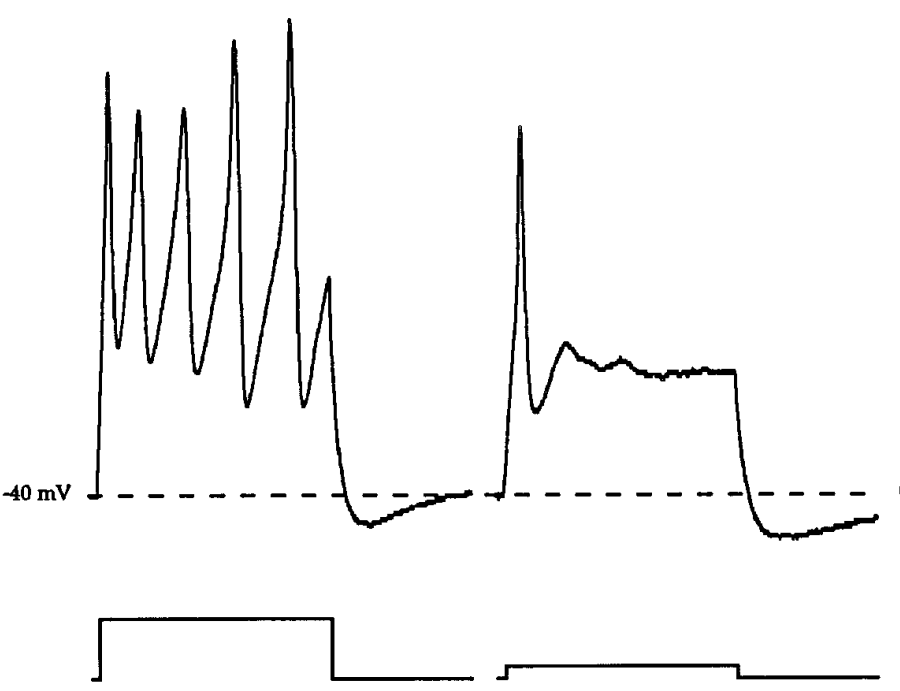

reduced glutathione, $5 \mathrm{~mm} \mathrm{MgCl} 2,1 \mathrm{mg} / \mathrm{ml}$ glucose, 20 mM EGTA, 4.14 $\mathrm{CaCl}_{2}, 470 \mathrm{~mm} \mathrm{CsOH}, 100 \mathrm{~mm}$ TEA-OH, $570 \mathrm{~mm}$ aspartate, $5 \mathrm{~mm}$ ATP, $0.1 \mathrm{~mm}$ GTP, pH 7.3. External solution was ASW in which choline chloride had been substituted for $\mathrm{NaCl}$ to remove sodium current. $\mathrm{Pi}$ pettes for measuring juvenile calcium currents were SYLGARD-coated to reduce capacitative noise. Basal $I_{\mathrm{Ca}}$ was revealed by holding at $-40 \mathrm{mV}$ and stepping to $+90 \mathrm{mV}$ in thirteen $10 \mathrm{mV}$ steps with a $5 \mathrm{sec}$ interpulse interval. Protein kinase C (PKC)-sensitive calcium current in combination with the basal calcium current was elicited using the same protocol after addition of $20 \mathrm{~mm}$ 12-O-tetradecanoyl-phorbol-13-acetate (TPA; Sigma). Acute effects of PKC activators on bag cell neurons are prevented during whole-cell recording (Strong et al., 1987) (T. Nick, unpublished observations). Thus, different sets of neurons from the same culture dish were recorded before and after the addition of TPA. Thus, the magnitude of PKC-activated calcium current could only be estimated. Inactive 4- $\alpha$-phorbol (20 mM) was used as a control phorbol ester.

As described previously (Kaczmarek and Strumwasser, 1984), the amount of sodium current expressed in bag cell neurons in culture was quite variable. Thus, the amplitude of this current was not compared in adult and juvenile neurons. TTX-sensitive inward current was noted in a subset of both adult and juvenile neurons (T. Nick, unpublished observations).

Values for raw currents were obtained using the ClampFit subprogram of pClamp 6 (Axon Instruments). Subtraction of currents to observe $I_{\mathrm{KV} 2}$ was also achieved using ClampFit. Peak values were taken for $I_{\mathrm{KV} 2}$. Because of the low signal-to-noise ratio in juvenile $I_{\mathrm{KA}}$ traces, both adult and juvenile traces were smoothed with a post hoc Gaussian filter (Frequency $10 \mathrm{kHz}$; pClamp) before peak detection. Also because of noise considerations, average current values were obtained at the end of the pulse for $I_{\mathrm{KV} 1}$ and $I_{\mathrm{KCa}}(280-300 \mathrm{msec})$. Average current values near the peak likewise were obtained for $I_{\mathrm{Ca}}(20-40 \mathrm{msec})$. Raw current values were converted to current density values by dividing by the cell capacitance, which is a measure of membrane surface area. Current densities were analyzed further using Origin technical graphics and data analysis program (Microcal, Northampton, MA). A one-way ANOVA was used for analysis of calcium dependence of prolonged depolarizations and of spike number and AHP size in response to a $500 \mathrm{msec}$ current pulse in cells in culture. The StatView statistics program (Abacus Concepts, Berkeley, CA) was used for calculation of two-way ANOVAs. Signifi-
Figure 6. As in intact preparations, repetitive firing occurs in adult, but not juvenile bag cell neurons in dissociated cell culture. Current pulses are shown below voltage traces. Because of differences in input resistance, a smaller amount of current was required to trigger an action potential in juvenile neurons $(B)$ compared to adult neurons $(A)$. The response of a juvenile neuron that was injected with current equal to that used in adult neurons $(0.5 \mathrm{nA})$ is shown in $C$. cance was determined with a post hoc Bonferroni/Dunn test. Data are presented as mean \pm SEM.

\section{RESULTS}

\section{Intact ganglia}

In response to pleural-abdominal connective stimulation, all adult bag cell neurons exhibited an afterdischarge, characterized by a period of prolonged depolarization and repetitive firing (Fig. 1A) (Kupfermann and Kandel, 1970). Intracellular microelectrode recordings from bag cell neurons from immature Aplysia revealed a developmental period during which neurons were incapable of afterdischarge. Unlike adult bag cell neurons, these cells did not exhibit afterdischarge in response to pleural-abdominal connective stimulation. Instead, they responded with small depolarizations which, with repeated connective stimulation, occasionally summated and produced single action potentials (Fig. 1B).

To maximize the possibility of afterdischarge, ganglia isolated from mature and immature Aplysia were exposed to the potassium channel blocker TEA (75 $\mathrm{mM})$. In adult neurons, this agent promotes the activation of afterdischarge (Kaczmarek et al., 1982). In juvenile bag cell neurons that failed to discharge in the absence of TEA, the presence of TEA also did not promote afterdischarge. That is, TEA did not enable afterdischarge in juvenile neurons that failed to discharge in response to connective stimulation alone. Moreover, there was a systematic and progressive trend for older animals to exhibit an afterdischarge. In vertebrates, weight is a critical determinant of sexual development (Frisch, 1974). Using weight as a determinant of the developmental status of the animals, we found that body weight accurately predicted the fraction of animals capable of afterdischarge in the range 2.1-241.2 gm (Fig. 2).

In the presence of $75 \mathrm{~mm}$ TEA, juvenile bag cell neurons that 

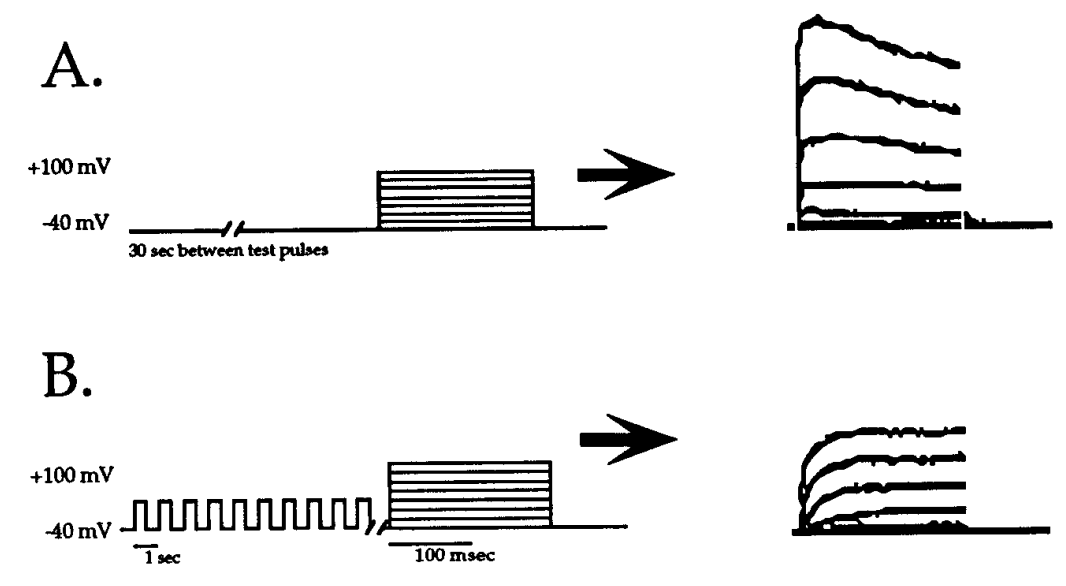

Figure 7. Stimulus protocols for revealing total and noninactivating delayed-rectifier potassium currents. Inactivating delayed-rectifier was observed by subtracting the noninactivating $(B)$ from the total $(A)$ delayed-rectifier current. BAPTA $(10 \mathrm{mM})$ was used in the pipette to remove calciumdependent potassium current.

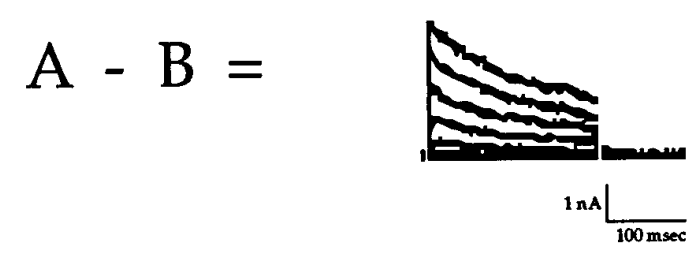

did not afterdischarge did exhibit prolonged depolarizations, preceded by single spikes, in the absence of repetitive firing (Fig. 3). These depolarizations occurred spontaneously in TEA, but could also be triggered by connective shock (in TEA). The duration of these depolarizations significantly increased with time in TEA (10-15 min in TEA: $2.5 \pm 0.2 \mathrm{sec} ; 20-25 \mathrm{~min}$ in TEA: $8.2 \pm 1.7$ sec, $n=6$ ganglia; $p<0.001$ ), perhaps because of slow diffusion of TEA into the ganglion. Because voltage plateaus are calciumdependent in many systems (see, for example, Kiehn, 1991; Barnes and Deschenes, 1992), we hypothesized that lowering the extracellular calcium concentration would decrease the voltage amplitude of the initial spike that precedes all TEA-induced prolonged depolarizations. Indeed, lowering the concentration of extracellular calcium significantly decreased the amplitude of the initial action potential (Fig. 4; $11 \mathrm{~mm} \mathrm{Ca}^{2+}: 52.3 \pm 3.2 \mathrm{mV} ; 2 \mathrm{~mm}$ $\mathrm{Ca}^{2+}: 30 \pm 5.8 \mathrm{mV} ; n=3$ ganglia; $\left.p<0.005\right)$. During these experiments, we also noted that the duration of the depolarizations increased after lowering the extracellular calcium concentration (Fig. 4 ; $11 \mathrm{~mm} \mathrm{Ca}^{2+}: 2.8 \pm 0.8 \mathrm{sec} ; 2 \mathrm{~mm} \mathrm{Ca}^{2+}: 47.3 \pm 7.3$ $\mathrm{mV} ; n=3$ ganglia; $p<0.002$ ) To investigate further the calcium dependence of depolarization duration, we repeated the above experiments with $9 \mathrm{mM} \mathrm{BaCl}_{2}$ added to the $2 \mathrm{mM} \mathrm{Ca}^{2+}$ solution. Barium was used so that we could observe effects specific to the calcium ion (although barium can interact with some potassium channels; Meech, 1974; Ribera and Spitzer, 1987) without a decrease in current flow carried by divalent cations. We found that, even with barium substitution, lowering the extracellular calcium concentration resulted in a significant increase in duration of depolarization $\left(11 \mathrm{mM} \mathrm{CaCl}_{2}: 10.0 \pm 1.1 \mathrm{sec} ; 2 \mathrm{mM} \mathrm{CaCl}_{2}\right.$, $9 \mathrm{mM} \mathrm{BaCl}_{2}: 49.6 \pm 5.2 \mathrm{sec} ; n=6$ ganglia; $\left.p<0.0001\right)$. The finding that the duration of depolarization increased after lowering the extracellular calcium concentration suggests the presence of a calcium-activated potassium current $\left(I_{\mathrm{KCa}}\right)$ or an inward current that is inactivated by calcium, because lowering calcium has the effect of prolonging depolarization in the cell. Below we report that, as with adult bag cell neurons (Fink et al., 1988), juvenile neurons express $I_{\mathrm{KCa}}$. Moreover, the current density of $I_{\mathrm{KCa}}$ decreases with development, such that juveniles have more of this current than adults.

Adult bag cell neurons are extensively electrically coupled (Haskins and Blankenship, 1979; Kaczmarek et al., 1979). Lack of coupling between bag cell clusters might explain the lack of afterdischarge in juvenile neurons (Fig. 1). To test this hypothesis, bag cell neurons in opposite clusters from the same juvenile ganglion were recorded simultaneously ( $n=6$ ganglia). As shown in Figure 5, depolarizations that occurred spontaneously in the presence of TEA occurred simultaneously in two cells from opposite clusters; indicating that electrical coupling between bag cell clusters is already established at this developmental stage. These data suggest that lack of connectivity among juvenile bag cell neurons is not sufficient to explain the lack of afterdischarge in these cells.

\section{Isolated neurons}

To determine whether the lack of afterdischarge capacity in juvenile bag cell neurons might be explained by regulation of intrinsic electrophysiological properties, we obtained whole-cell recordings from neurons isolated in culture $(18-26 \mathrm{hr})$. We found that electrophysiological properties of the bag cell neurons systematically change during the developmental onset of afterdischarge. The input resistance of juvenile bag cell neurons is larger than that of adults (juvenile: $2620 \pm 529 \mathrm{M} \Omega, n=10$; adult: $893 \pm 347 \mathrm{M} \Omega, n=8 ; p<$ $0.03)$. Therefore, more current was required to depolarize adult neurons compared with juvenile neurons. The amount of current we injected was determined in pilot experiments, using the criterion of identifying a minimum amount of current required to trigger at least one spike. Consistent with results obtained in the intact ganglion, a majority of juvenile bag cell neurons in culture were incapable of repetitive firing in response to a sustained current pulse. As shown in Figure 6 , in response to a $500 \mathrm{msec}$ current injection $(0.1 \mathrm{nA}$ in juvenile neurons; $0.5 \mathrm{nA}$ in adult neurons), juvenile bag cell neurons, in contrast to adult cells, rarely exhibited more than one action potential (juvenile: $1.2 \pm 0.12$ spikes, $n=16$; adult: $3.1 \pm 0.90$ spikes, 

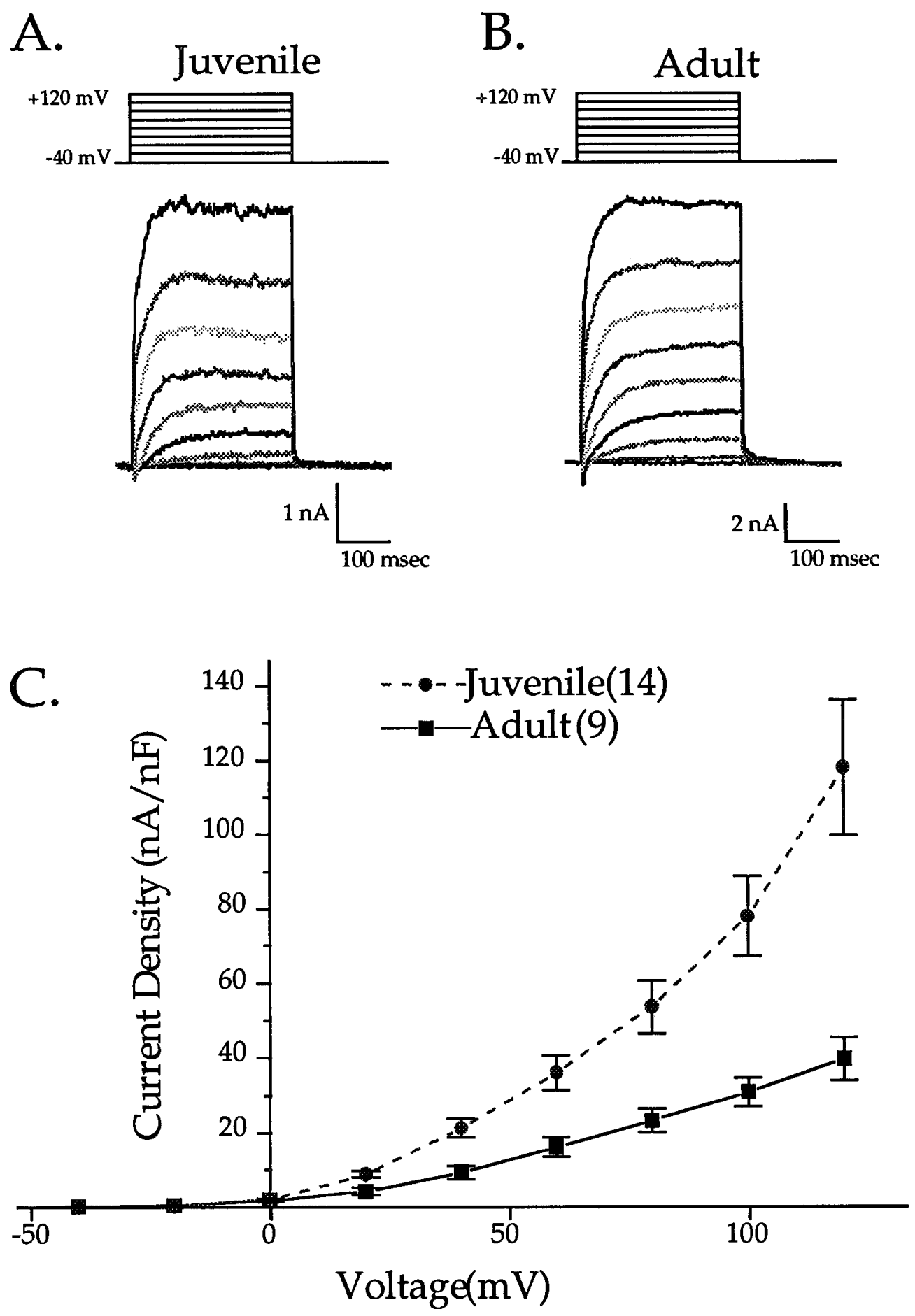

Figure 8. Noninactivating delayedrectifier $\left(I_{\mathrm{KV} 1}\right)$ current density decreases with maturation in the bag cell neurons. $A$ and $B$ show representative raw current data from single cells with voltage steps above from juvenile and adult neurons, respectively. Note the change in current scale. $C$ shows group peak current density data (mean \pm SEM) versus voltage. Stimulus protocol is depicted in Figure $7 B$.

$n=9 ; p<0.01)$. To extend the comparison, we also increased the current in juvenile neurons to be equal to that used in adult cells. Even under these conditions, juvenile neurons showed reduced excitability compared to adults (Fig. $6 C$ ). Further, the AHP in juvenile bag cell neurons achieved significantly more hyperpolarized membrane potentials than in adult neurons after a $500 \mathrm{msec}$ current injection (Fig. 6; maximum negative voltage: adult ( $0.5 \mathrm{nA}),-45.8 \pm$ $0.73 \mathrm{mV}, n=9$; juvenile (0.1 nA), $-51.5 \pm 0.80 \mathrm{mV}, n=13 ; p<$ $0.001)$. This may reflect the higher $I_{\mathrm{KCa}}$ current density of juveniles (see below), because $I_{\mathrm{KCa}}$ is thought to underlie the slow AHP in some systems (Barrett and Barrett, 1976).
The finding that, in contrast to adult neurons, juvenile bag cell neurons lack the capacity for repetitive firing in culture indicates that intrinsic biophysical properties of the bag cell neurons themselves are regulated very late in development. We next sought to examine these electrophysiological changes in detail.

Three potassium currents decrease with development of the afterdischarge

Delayed-rectifier $\mathrm{K}^{+}$currents were examined with $10 \mathrm{~mm}$ BAPTA in the pipette solution to remove $I_{\mathrm{KCa}}$. As shown in Figure $7 B$, 

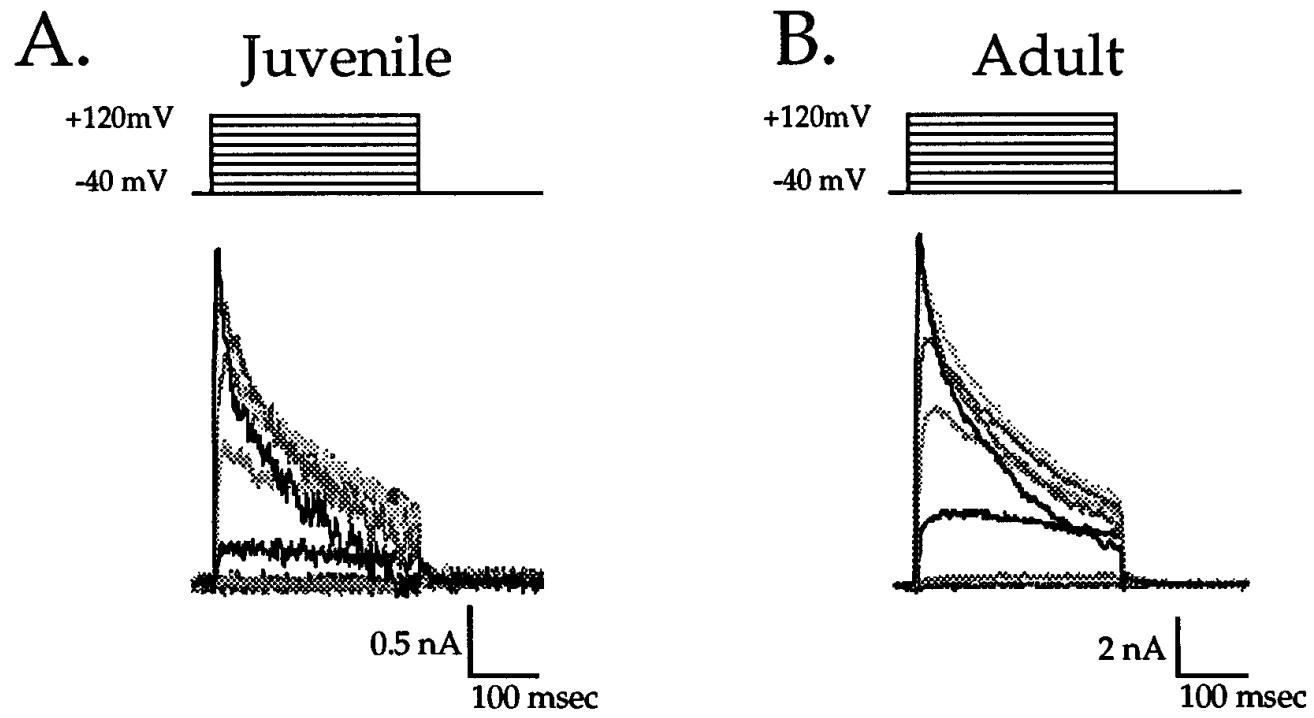

Figure 9. Inactivating delayedrectifier $\left(I_{\mathrm{KV} 2}\right)$ current density decreases with development in the bag cell neurons. $A$ and $B$ are representative raw currents. Note the change in current scale. $C$ is the group peak current density-voltage relationship. Stimulus protocol is described in Figure 7.
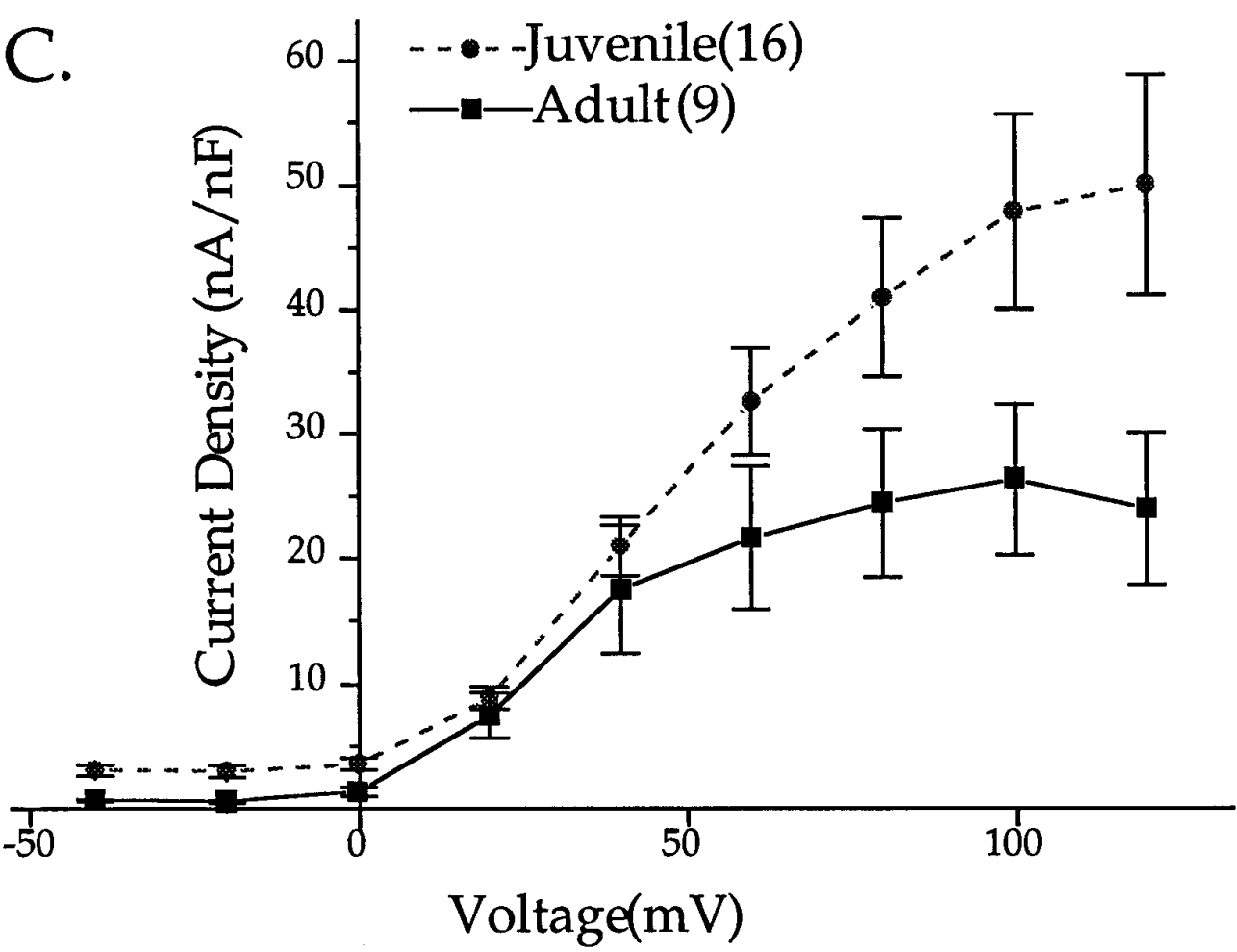

$I_{\mathrm{KV} 1}$ was studied in the absence of the inactivating $I_{\mathrm{KV} 2}$ through stimulation with a train of inactivating prepulses immediately before each test pulse. The total delayed-rectifier $\mathrm{K}^{+}$current was obtained by waiting $30 \mathrm{sec}$ between each test pulse to allow for recovery from inactivation (Fig. $7 A$ ). Subtraction of $I_{\mathrm{KV} 1}$ from the total delayed-rectifier $\mathrm{K}^{+}$current revealed $I_{\mathrm{KV} 2}$ (Fig. 7). Although the absolute values for all currents in adult bag cell neurons were much larger than in juvenile neurons, when cell size was taken into account (by dividing by the membrane capacitance), juvenile neurons were found to have greater current density values for three potassium currents:

(1) A noninactivating delayed rectifier $\left(I_{\mathrm{KV} 1}\right.$; juvenile peak current density at $+120 \mathrm{mV}: 117.7 \pm 18.3 \mathrm{nA} / \mathrm{nF}, n=14$; adult:
$39.6 \pm 5.8 \mathrm{nA} / \mathrm{nF}, n=9 ; p<0.0001$ from +40 to $+120 \mathrm{mV}$ ) (see Fig. 8).

(2) An inactivating delayed-rectifier $\left(I_{\mathrm{KV} 2}\right.$; Fig. 9 ; juvenile at $+120 \mathrm{mV}: 45.4 \pm 8.3 \mathrm{nA} / \mathrm{nF}, n=16$; adult: $25.3 \pm 7.7 \mathrm{nA} / \mathrm{nF}$, $n=9 ; p<0.001$ from +60 to $+120 \mathrm{mV})$. In addition to current density, the voltage dependence of $I_{\mathrm{KV} 2}$ changed with development. Specifically, Boltzmann fits of the peak conductancevoltage relationship revealed that the voltage at which halfactivation occurs shifts to more hyperpolarized potentials with development (juvenile: $36.0 \pm 1.5 \mathrm{mV}, n=12$; adult: $25.4 \pm$ $3.2 \mathrm{mV}, n=7 ; p<0.005)$, whereas the slope factor for these fits does not change (juvenile: $6.3 \pm 0.3 \mathrm{mV}, n=12$; adult: $7.4 \pm 0.9 \mathrm{mV}, n=7$; not significant). The rate of $I_{\mathrm{KV} 2}$ 


\section{A. Juvenile}

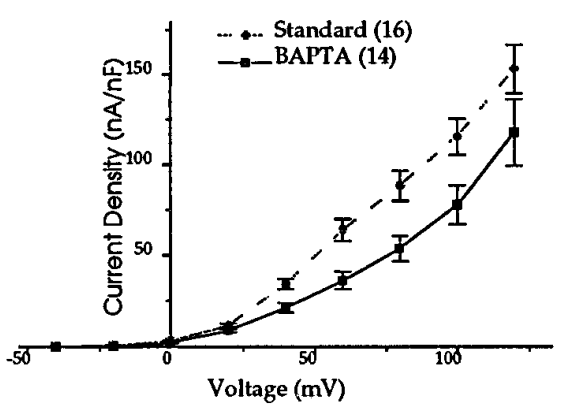

\section{B. Adult}

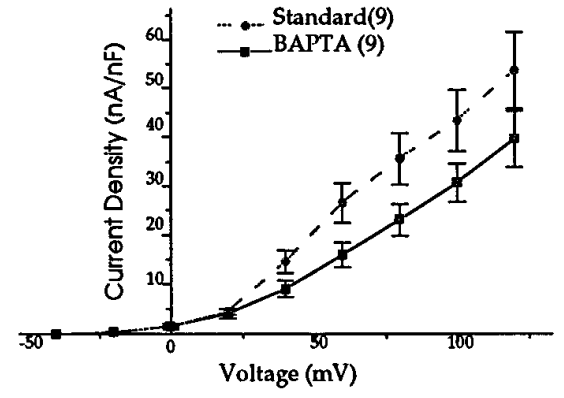

\section{Subtracted Current Densities}

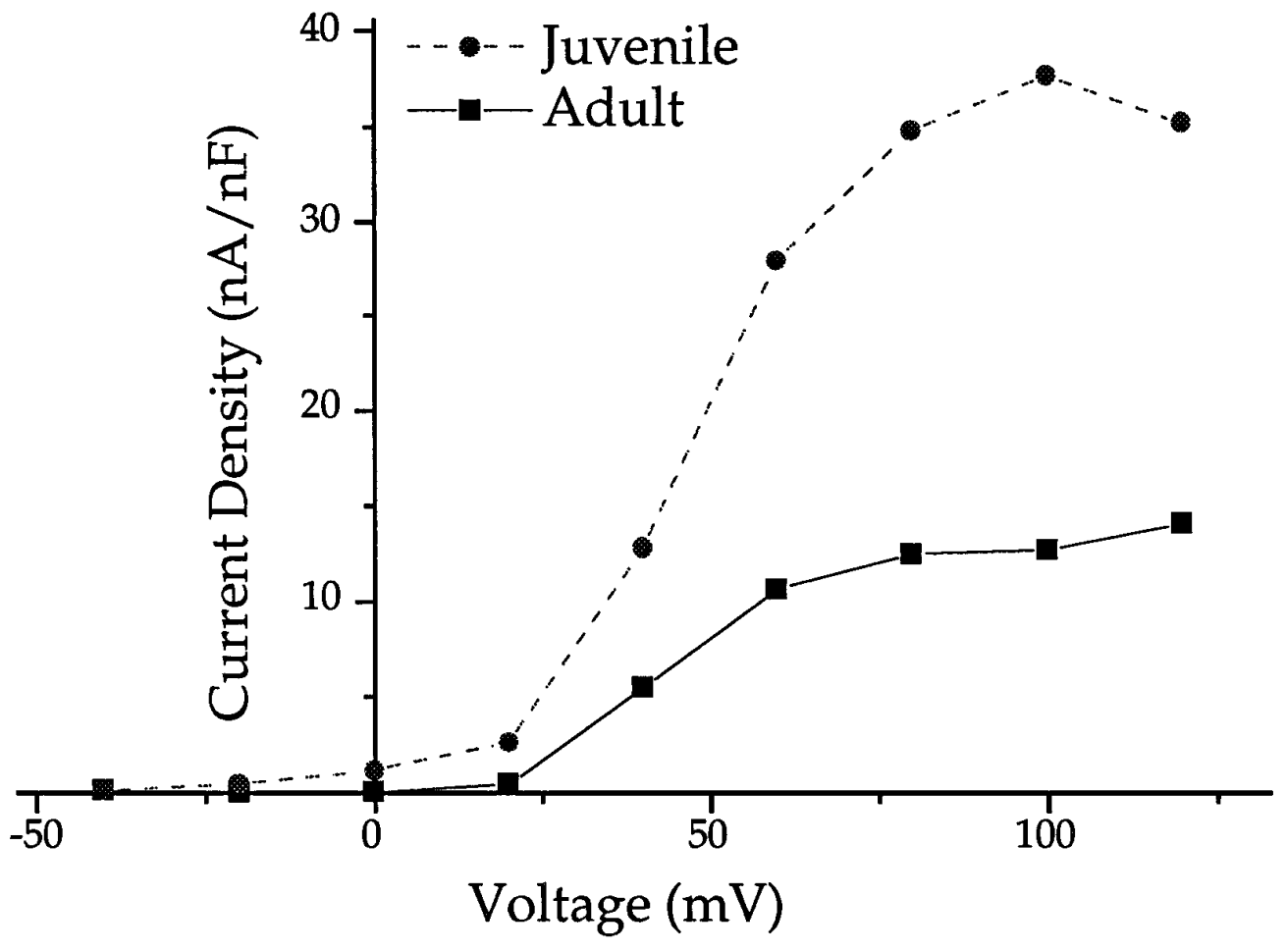

Figure 10. Intracellular BAPTA $(10 \mathrm{mM})$ decreases potassium current density in both juvenile and adult bag cell neurons. This observation allows estimation and comparison of calcium-dependent potassium current $\left(I_{\mathrm{KCa}}\right)$ magnitudes. Estimated $I_{\mathrm{KCa}}$ is shown in $C$. A train protocol (described in Fig. 7B) was used to remove inactivating potassium current. inactivation also appeared to change with development. However, the decay phase of this current could not be fitted with a single exponential. Therefore, we measured the percent of current left after $120-140 \mathrm{msec}$ into the pulse (data points during 120-140 msec were averaged and subtracted from the peak current value). We found that this measure of inactivation is similar in adult and juvenile bag cell neurons across a range of voltages (juvenile at $+40 \mathrm{mV}: 59.3 \pm 8.5 \%$; adult: $75.6 \pm$ $18.5 \%)$.

(3) A calcium-dependent potassium current ( $I_{\mathrm{KCa}}$; Fig. 10). $I_{\mathrm{KCa}}$ was studied by subtracting noninactivating potassium currents recorded with pipette solution that contained $10 \mathrm{~mm}$ BAPTA from those recorded with Standard pipette solution. $I_{\mathrm{KCa}}$ was seen in both juvenile (Fig. 10A; Standard at $+120 \mathrm{mV}$ : $152.9 \pm 13.6$
$\mathrm{nA} / \mathrm{nF}, n=16$; BAPTA: $117.7 \pm 18.3 \mathrm{nA} / \mathrm{nF}, n=14 ; p<0.001$ from +40 to $+120 \mathrm{mV}$ ) and adult neurons (Fig. 10B; Standard at $+120 \mathrm{mV}: 53.6 \pm 7.9 \mathrm{nA} / \mathrm{nF}, n=9$; BAPTA: $39.6 \pm 5.8 \mathrm{nA} / \mathrm{nF}$, $n=9 ; p<0.004$ from +40 to $+120 \mathrm{mV})$. The magnitude of $I_{\mathrm{KCa}}$ was inferred by subtracting the peak current density recorded with BAPTA in the pipette from that with Standard solution (Fig. $10 C$ ). The estimated $I_{\mathrm{KCa}}$ with no error bars is shown because different sets of neurons were used for the BAPTA and Standard measurements. For both juveniles and adults, $I_{\mathrm{KCa}}$ was $\sim 35 \%$ of total noninactivating potassium current (juvenile: $35.31 \pm 3.6 \%$; adult: $33.7 \pm 2.6 \%$; not significant). Thus, the ratio of these currents appears to remain rather constant with development.

The membrane capacitance of juvenile bag cell neurons was significantly smaller than that of adult neurons (juvenile: $35.1 \pm$ 


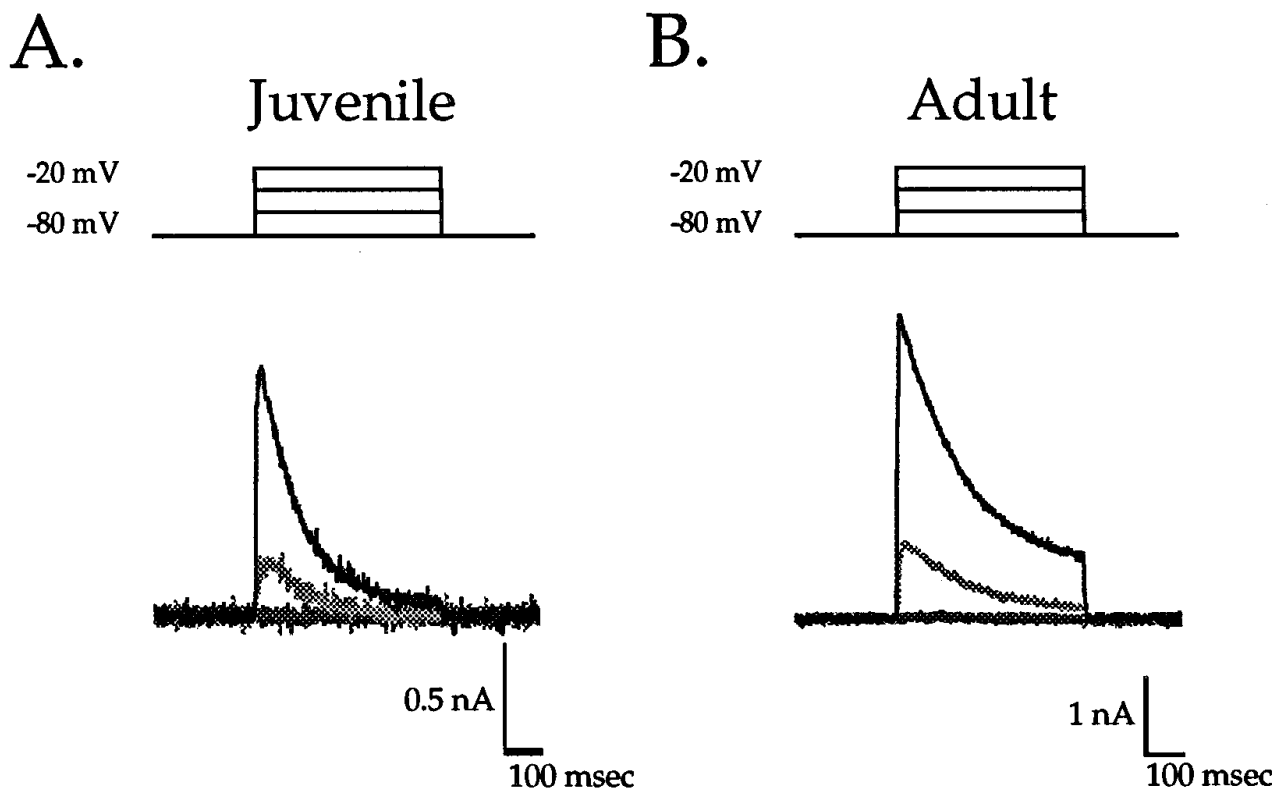

Figure 11. A-type transient inactivating potassium $\left(I_{\mathrm{KA}}\right)$ current density increases with development in the bag cell neurons. $A$ and $B$ are representative raw currents. Note the change in current scale. Comparison of current densities in $C$ reveals that adult neurons have a larger peak $\mathrm{A}$ current density at $-40 \mathrm{mV}$ than juveniles.

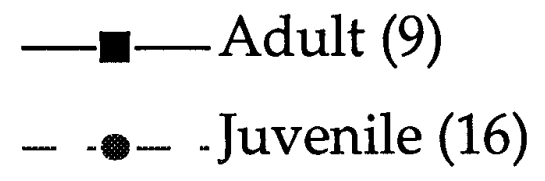

$5.3 \mathrm{pF}, n=16$; adult: $271.3 \pm 63.9 \mathrm{pF}, n=9 ; p<0.001)$. Somata diameters of juvenile bag cell neurons were also significantly smaller than those of adult neurons (juvenile: $12.5 \pm 0.4 \mu \mathrm{m}, n=$ 16; adult: $30.4 \pm 1.6 \mu \mathrm{m}, n=9 ; p<0.001)$, which likely contributed to the higher input resistance of the juvenile neurons.

A-type potassium current increases with the development of afterdischarge

In addition to the three potassium currents described above, which decrease with development, we also found that a fourth potassium current, the A-type transient inactivating current ( $I_{\mathrm{KA}}$; Fig. 11), significantly increased during the developmental onset of afterdischarge (juvenile: $1.0 \pm 0.3 \mathrm{nA} / \mathrm{nF}, n=16$; adult: $2.6 \pm 0.8 \mathrm{nA} / \mathrm{nF}$, $n=9 ; p<0.05$ at $-40 \mathrm{mV})$, in contrast to the downregulation of the other outward currents. We found that the time constant for inactivation of $I_{\mathrm{KA}}$ did not change during the same developmental period (juvenile: $108.9 \pm 24.7, n=8$; adult: $143.4 \pm 13.9, n=9$; not significant). Because some outward currents are downregulated during development, whereas others are upregulated, these data collectively show that the developmental modification of these currents does not result from a general, nonspecific change. 
A.

\section{Juvenile}
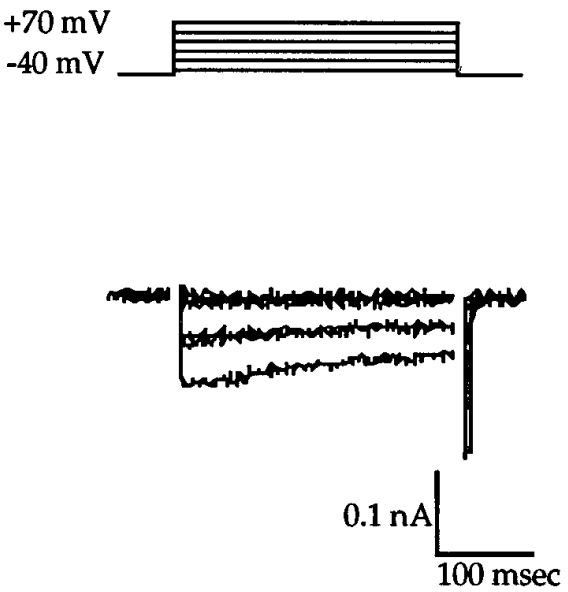

B.

\section{Adult}

$+70 \mathrm{mV}$

$-40 \mathrm{mV}$

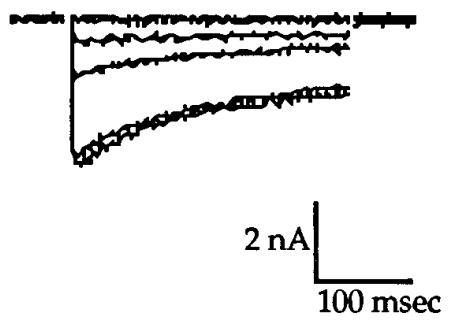

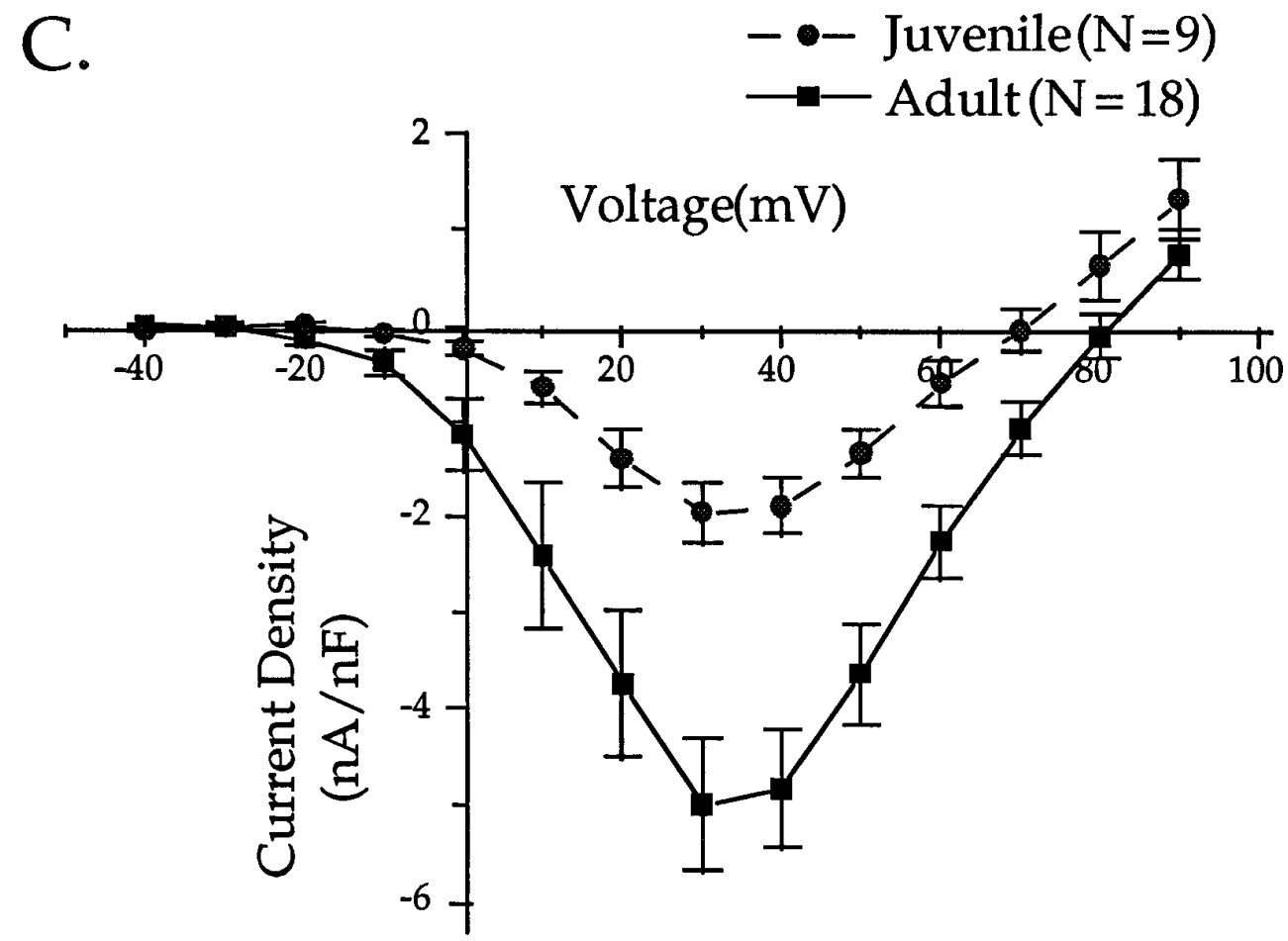

Figure 12. Bag cell neuron basal calcium $\left(I_{\mathrm{ca}}\right)$ current density increases with development. $A$ and $B$ are representative raw currents of juvenile and adult neurons, respectively. Note the change in current scale. The current density-voltage curves in $C$ show that adult neurons have larger peak calcium current density than juveniles.

Two calcium currents increase with development of the afterdischarge

We also examined the developmental patterns of expression of two calcium currents: (1) a basal calcium current, which is expressed without experimental manipulation, and (2) a PKCsensitive calcium current, which is expressed after the activation of PKC in bag cell neurons. As shown in Figure 12, the basal voltage-sensitive calcium current in bag cells neurons significantly increases during the developmental onset of afterdischarge (ju- venile: $-1.9 \mathrm{nA} \quad / \mathrm{nF} \pm 0.3, n=9$; adult: $-5.0 \mathrm{nA} / \mathrm{nF} \pm 0.7, n=$ 18; $p<0.03$ from 0 to $+30 \mathrm{mV}$ ). We also found that the time constant for $I_{\mathrm{Ca}}$ inactivation does not change with development (juvenile: $140.4 \pm 9.1, n=14$; adult: $126.1 \pm 5.2, n=18$; not significant). Because an increased calcium current would be expected to increase neuronal excitability, the finding that calcium current density increases with development is consistent with the finding that adult bag cell neurons are more excitable than their juvenile counterparts. 


\begin{tabular}{|c|c|c|c|}
\hline & $\begin{array}{l}\text { Juvenile } \\
(<11 \text { gm })\end{array}$ & $\begin{array}{l}\text { Adult } \\
(>50 \mathrm{gm})\end{array}$ & $p<$ \\
\hline Resting potential (mV) & $-46.9 \pm 4.6$ & $-54.1 \pm 4.6$ & N.S. \\
\hline Spike number in response to $500 \mathrm{msec}$ current pulse & $1.2 \pm 0.1$ & $3.1 \pm 0.9$ & 0.01 \\
\hline Input resistance $(\mathrm{M} \Omega)$ & $2620 \pm 529$ & $893 \pm 347$ & 0.03 \\
\hline \multicolumn{4}{|l|}{ Peak current density $(\mathrm{nA} / \mathrm{nF})$} \\
\hline Noninactivating delayed-rectifier & $117.7 \pm 18.3$ & $39.6 \pm 5.8$ & 0.0001 \\
\hline Inactivating delayed-rectifier & $45.4 \pm 8.3$ & $25.3 \pm 7.7$ & 0.001 \\
\hline Calcium-dependent potassium (est.) & 37.6 & 14.0 & \\
\hline A-type potassium & $1.0 \pm 0.3$ & $2.6 \pm 0.8$ & 0.05 \\
\hline
\end{tabular}

The other calcium current examined is expressed only after activation of PKC (DeRiemer et al., 1985). The phorbol ester TPA was used to activate PKC and induce expression of this calcium current [Fig. 13; (-)-TPA peak current density at +30 $\mathrm{mV}:-5.0 \mathrm{nA} / \mathrm{nF} \pm 0.7, n=18 ;(+)$-TPA: $-10.8 \mathrm{nA} / \mathrm{nF} \pm 1.0$, $n=13 ; p<0.0001$ from 0 to $+30 \mathrm{mV}$ ]. Juvenile bag cell neurons do not show a significant increase in calcium current after the addition of TPA [Fig. 14; (-)-TPA: $-1.9 \mathrm{nA} / \mathrm{nF} \pm 0.3, n=9$; (+)-TPA: $-2.6 \mathrm{nA} / \mathrm{nF} \pm 0.4, n=9$; not significant]. Because PKC-sensitive calcium current is thought to underlie the increase in action potential height observed during afterdischarge (DeReimer et al., 1985), lack of this current or elements in its activation pathway is consistent with a lack of afterdischarge in juvenile neurons. As reported previously (DeRiemer et al., 1985), treatment with an inactive phorbol ester, 4- $\alpha$-phorbol, did not increase calcium current in adults [(-)-4- $\alpha$-phorbol: $-5.0 \mathrm{nA} / \mathrm{nF} \pm 0.69$, $n=18 ;(+)-4-\alpha$-phorbol: $-6.3 \mathrm{nA} / \mathrm{nF} \pm 1.65, n=4$; not significant). These data thus show that both the basal and the PKCsensitive calcium currents are upregulated during development.

\section{DISCUSSION}

We have shown that the ability to fire repetitively is systematically regulated during development in the bag cell neurons of Aplysia. To investigate intrinsic mechanisms underlying the regulation of electrical excitability, we have compared major ionic currents in adult and juvenile neurons. Indeed, the general developmental pattern of ionic current expression that we observe is consistent with the increase in the ability to fire repetitively seen during the maturation of afterdischarge: three potassium currents decrease and two calcium currents increase. In addition, a fourth potassium current $\left(I_{\mathrm{KA}}\right)$ increases with development. $I_{\mathrm{KA}}$, an outward current, might be expected to decrease excitability. However, $I_{\mathrm{KA}}$ has an important role in repetitive firing in other neurons (Connor and Stevens, 1971a,b); this current dominates the interspike interval, whereas other currents determine the characteristics of the action potential. Thus, increase in $I_{\mathrm{KA}}$ may contribute to the regulation of repetitive firing characteristics of mature bag cell neurons. Taken collectively, the selective developmental regulation of the six currents that we have examined may promote the progressive acquisition of the ability of bag cell neurons to exhibit the afterdischarge required for egg laying in the adult.
At developmental stages when juvenile bag cell neurons are incapable of repetitive firing, they nonetheless exhibit prolonged depolarizations

Although juvenile bag cell neurons did not fire repetitively in response to any stimulus (e.g., nerve shock, TEA), they did exhibit prolonged depolarizations in the presence of the potassium channel blocker TEA. Thus, lack of afterdischarge in these neurons appears to be attributable to a lack of capacity for repetitive firing, but not to the inability to express another feature of the mature afterdischarge, prolonged depolarization. Nonspecific cation currents are thought to underlie the depolarization that occurs during afterdischarge (Wilson and Kaczmarek, 1993; Loechner and Kaczmarek, 1994). Because juvenile neurons are capable of prolonged depolarization (in the presence of a potassium channel blocker), this suggests that they already express these nonspecific cation currents. This feature of immature neurons was advantageous, because it allowed us to describe precisely a limited number of currents that would most likely be involved in repetitive firing activity (see below). After further characterization of depolarizations observed in juvenile neurons, we found that the duration of depolarization increased with decreased extracellular calcium concentration. Assuming that calcium activates calcium-dependent potassium channels, leading to subsequent repolarization of the membrane, lowering extracellular calcium should result in longer depolarizations. Consistent with this idea, we find that juvenile neurons indeed have high calcium-dependent potassium current density.

As adult neurons are electrically coupled (Haskins and Blankenship, 1979; Kaczmarek et al., 1979), regulation of connectivity among juvenile neurons might be a potential mechanism for developmental control of afterdischarge. However, our finding that juvenile neurons that cannot afterdischarge are already electrically coupled does not support this hypothesis. Instead, we have found that the acquisition of the mature phenotype reflects progressive changes in the intrinsic ion current properties of the neurons. Some bag cell peptides (BCPs), which are released by the bag cell neurons, are autoexcitatory and may have roles in the generation of the afterdischarge (Rothman et al., 1983; Brown and Mayeri, 1989; Loechner and Kaczmarek, 1990, 1994). Developmental regulation of the expression of the BCPs or their transduction pathway may also contribute to intrinsic control of repetitive firing in the bag cell neurons. 


\section{Adult}

A.
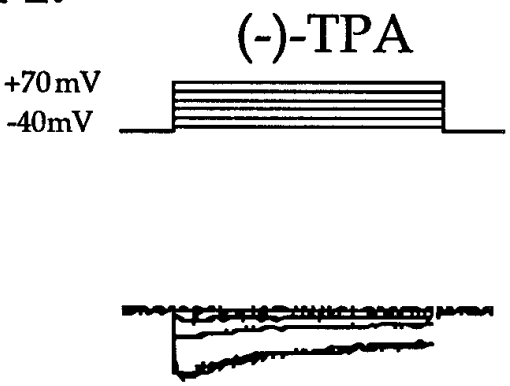

B.

$+70 \mathrm{mV}$
$-40 \mathrm{mV}$

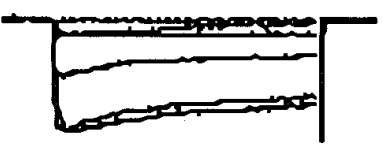

$2 n A$

$100 \mathrm{msec}$

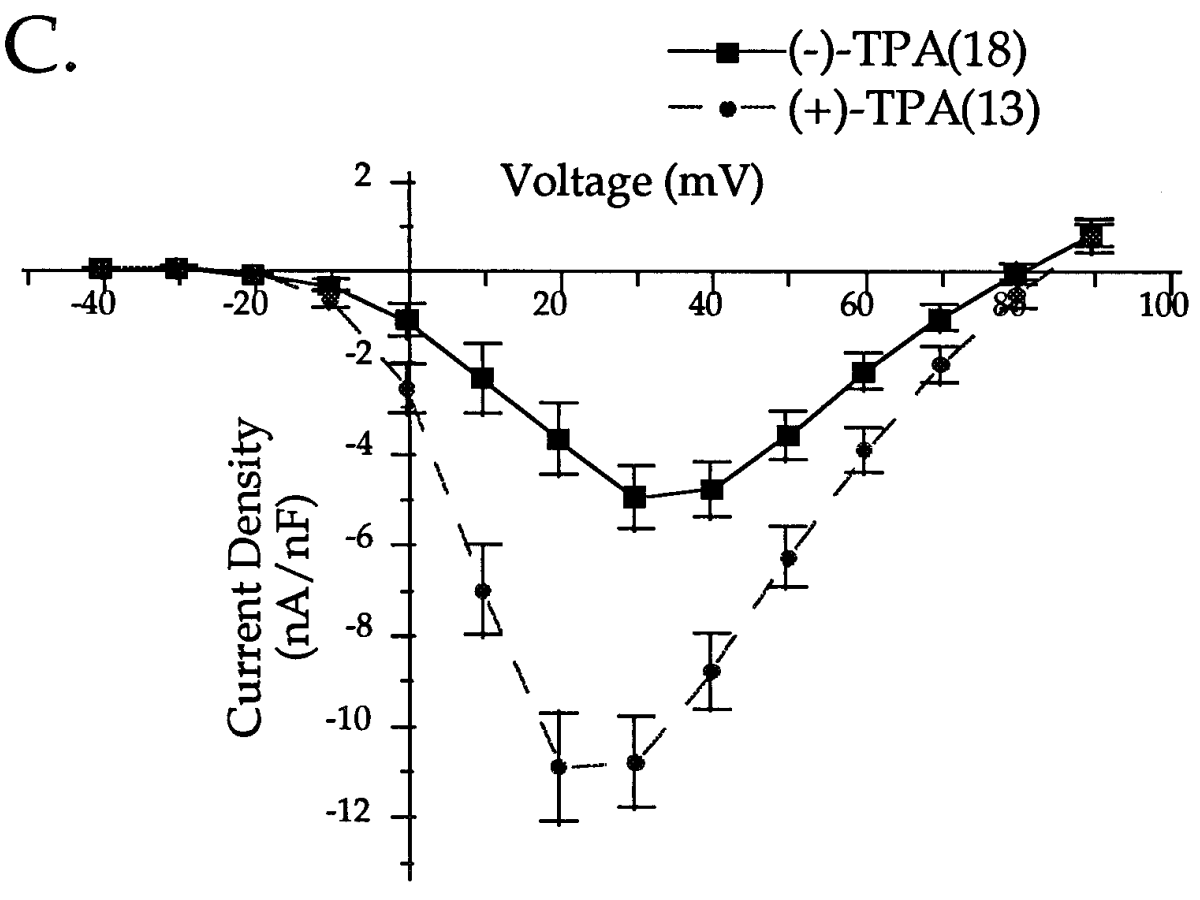

Figure 13. The phorbol ester TPA triggers a significant increase in calcium current in adult bag cell neurons. $A$ and $B$ show representative current traces from different neurons in the same culture dish before and after TPA, respectively. The effect of TPA can readily be detected in the current density-voltage relationship from adult neurons $(C)$.
Intrinsic properties of bag cell neurons change during development

Previous developmental studies that have examined the activity of neurons that fire repetitively in adulthood have begun the analysis only after the developmental onset of repetitive firing activity. For example, Prince and colleagues (McCormick and Prince, 1987; Hamill et al., 1991) found that neonatal neocortical pyramidal cells, like adult neurons, are capable of repetitive firing, but all major current densities examined were smaller than those of adults. As the authors point out, these studies were limited by the ability to recognize specific cell types and, therefore, could not examine currents before the onset of repetitive firing capacity. One of the major advantages of the bag cell neuron system in addressing these kinds of developmental questions is that the bag cell neurons are easily identified and can be studied before they express any repetitive firing activity.

In some adult systems, repetitively firing neurons that have been examined in vitro show decreases in potassium current concomitant with reacquisition of tonic firing and bursting capacity (Turrigiano et al., 1994, 1995; Mills and Pitman, 1995). These data are consistent with our finding that bag cell neurons show decreases in three of four potassium current densities examined during the developmental acquisition of repetitive firing capacity. Thus, as adult neurons in vitro begin to express the tonic firing pattern observed in vivo, they may be recapitulating a normal developmental process that underlies the emergence of repetitive firing. 


\section{Juvenile}
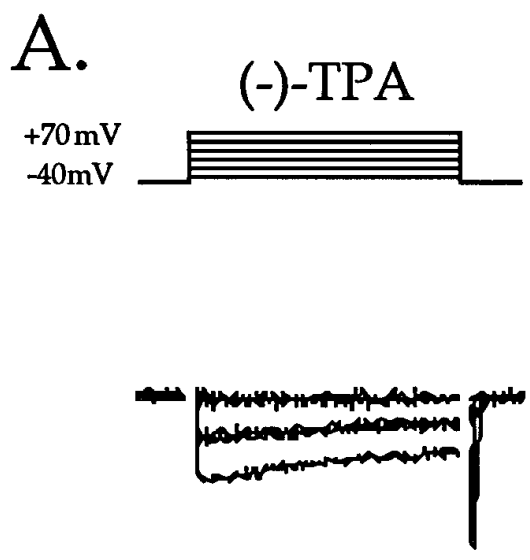

C.
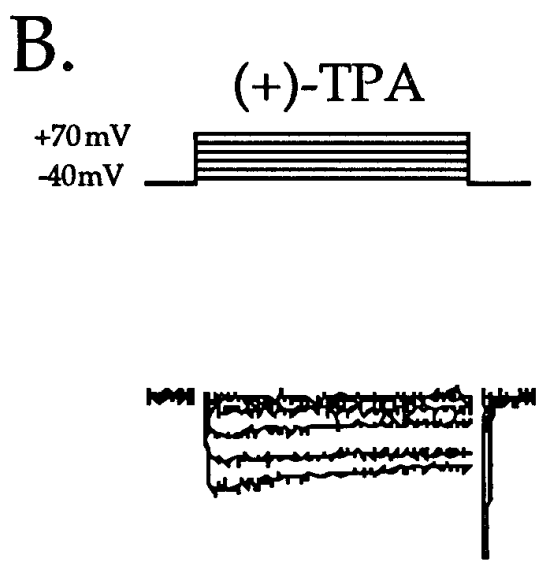

$0.1 \mathrm{nA}$

Figure 14. The phorbol ester TPA triggers little increase in calcium current in juvenile bag cell neurons. $A$ and $B$ show representative current traces from different neurons in the same culture dish before and after TPA, respectively. TPA induced a small increase in calcium current in juvenile bag cell neurons (C). However, this difference was not significant.

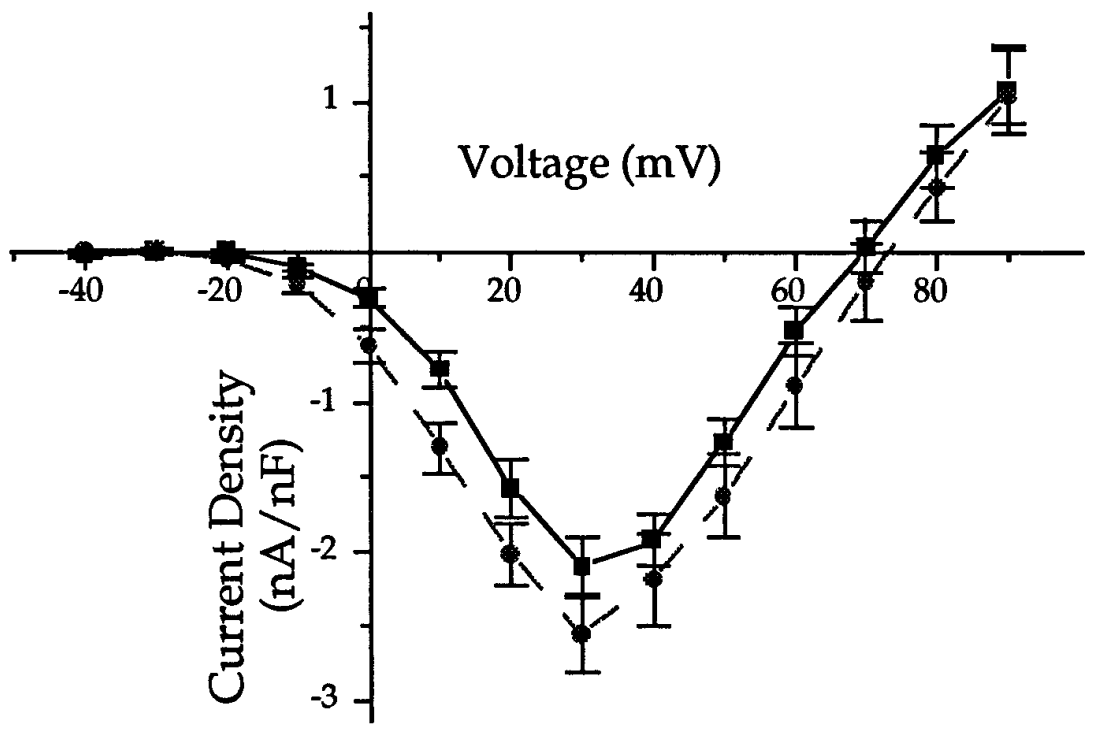

We have found that the intrinsic properties of bag cell neurons are systematically altered during development of the afterdischarge (Table 1). Our collective observations that some currents increase while some decrease indicate that the changes in ionic currents that we observe during development are both relatively specific and functionally coordinated. That is, if all currents increased or decreased together, one might explain the changes as simply reflecting general growth of the neuron. The observation that all currents examined except for A-type potassium current change in ways that would increase the capacity to fire repetitively, even though for different currents this means change in opposite directions, suggests that the specific developmental regulation of individual ion currents in this system may have functional significance.

Possible explanations for the changes in current density include changes in post-translational modification or decreases in channel number through alterations of turnover rates and changes in transcription or translation. The finding that some potassium current densities decrease while the membrane surface area (as measured by capacitance) increases suggests that another possible mechanism for the current density reduction that we observe during development may be simple addition of membrane. In this case, the same amount of current would flow across the membrane, but the potential difference would not change as much or 
as rapidly because of the requirement of charging and discharging the larger membrane capacitance in cells with a greater surface area. This could be a general regulatory mechanism used during neuronal development, because many neurons show increases in membrane surface area during maturation through the elaboration of dendritic trees, axonal arborizations, and synaptic contacts. This rather straightforward mechanism for modulation of current density during development may not have been fully appreciated previously because of the study of cultured neurons that do not possess the extensive processes seen in vivo. Examination of cultured bag cell neurons partially alleviates this problem because their soma surface area increases with development, along with process elaboration (McAllister et al., 1983) (present study). However, this potential mechanism of current density reduction could not explain the changes seen in the voltage dependence of the inactivating delayed rectifier. Changes in this current property may result from expression of different channel subunits and/or the recombination of existing subunits. On the other hand, possible mechanisms for increasing current density, which may explain the changes we observe in $I_{\mathrm{KA}}$ and $I_{\mathrm{Ca}}$, might include increases in channel density and changes in post-translational modification.

A common observation that has emerged in the analysis of development of ionic currents is that a majority of neuronal potassium currents that have been examined increase with development in vivo (for review, see Ribera and Spitzer, 1992). Therefore, our finding that three potassium currents decrease with development in the bag cell neurons may appear surprising. However, most other neuronal cell types examined were neither repetitively firing nor neuroendocrine. Moreover, an instructive exception to this general observation (of increased potassium current with development) is rat pineal neurons (Aguayo, 1989) which, like the bag cell neurons, show a decrease in potassium current with development. These neurons are also neuroendocrine in function. Premature activity of neuroendocrine cells and subsequent expression of reproductive behaviors before sexual maturation may cause increased mortality and decreased growth rate, without adding the benefits of reproduction (Stearns, 1976; Lima and Dill, 1990). Also, inappropriate hormone secretion may have teratogenic effects. Thus, neuroendocrine systems might not conform, in general, to the developmental programs of other neurons. Our previous findings that juvenile bag cell neurons contain and can secrete the bioactive peptide Egg Laying Hormone (Nick et al., 1996) support a potential role for regulation of hormone secretion at the level of neuronal electrical excitability.

Our results, in combination with data from other cell types (for review, see Ribera and Spitzer, 1992), support the hypothesis that neurons selectively regulate the expression of their ionic currents during development. Our data also suggest that the way different neuronal types regulate their ionic currents may vary significantly during each specific window of development. This variation likely reflects differences in the final neuronal electrophysiological phenotype (e.g., repetitive firing, bursting, quiescent) and the many aspects of development in which ion channels play a role, including cell proliferation (Gargus et al., 1993), construction of neural circuits (LeVay et al., 1981), regulation of neuronal differentiation (Jones and Ribera, 1994) (for review, see Spitzer, 1991), and regulation of hormone secretion (present study). Thus, examination of the development of different neuronal phenotypes and the specific changes that underlie their expression may reveal general rules to which all neurons conform. Moreover, investigation of exceptions to these rules may provide a better understanding of neuronal differentiation in the context of the overall functional development of the nervous system.

\section{REFERENCES}

Aguayo LG (1989) Post-natal development of $\mathrm{K}^{+}$currents studied in isolated rat pineal cells. J Physiol (Lond) 414:283-300.

Barnes S, Deschenes MC (1992) Contribution of Ca and Ca-activated Cl channels to regenerative depolarization and membrane bistability of cone photoreceptors. J Neurophysiol 68:745-755.

Barrett EF, Barrett JN (1976) Separation of two voltage-sensitive potassium currents, and demonstration of a tetrodotoxin-resistant calcium current in frog motoneurons. J Physiol (Lond) 255:737-774.

Branton WD, Arch S, Smock T, Mayeri E (1978a) Evidence for mediation of a neuronal interaction by a behaviorally active peptide. Proc Natl Acad Sci USA 75:5732-5736.

Branton WD, Mayeri E, Brownell P, Simon SB (1978b) Evidence for local hormonal communication between neurones in Aplysia. Nature 274:70-72.

Brown RO, Mayeri E (1989) Positive feedback by autoexcitatory neuropeptides in neuroendocrine bag cells of Aplysia. J Neurosci 9:1443-1451.

Conn PJ, Kaczmarek LK (1989) The bag cell neurons of Aplysia: a model for the study of the molecular mechanisms involved in the control of prolonged animal behaviors. Mol Neurobiol 3:237-273.

Connor JA, Stevens CF (1971a) Voltage clamp studies of a transient outward membrane current in gastropod neural somata. J Physiol (Lond) 213:21-30.

Connor JA, Stevens CF (1971b) Prediction of repetitive firing behavior from voltage clamp data on an isolated neurone soma. J Physiol (Lond) 213:31-53.

DeRiemer SA, Strong JA, Albert KA, Greengard P, Kaczmarek LK (1985) Enhancement of calcium current in Aplysia neurones by phorbol ester and protein kinase C. Nature 313:313-316.

Dudek FE, Tobe SS (1978) Bag cell peptide acts directly on ovotestis of Aplysia californica: basis for an in vitro bioassay. Gen Comp Endocrinol 36:618-627.

Dudek FE, Cobbs JS, Pinsker HM (1979) Bag cell electrical activity underlying spontaneous egg laying in freely behaving Aplysia brasiliana. J Neurophysiol 13:319-326.

Fink LA, Connor JA, Kaczmarek LK (1988) Inositol trisphosphate releases intracellularly stored calcium and modulates ion channels in molluscan neurons. J Neurosci 8:2544-2555.

Frisch RE (1974) Critical weight at menarche, initiation of the adolescent growth spurt, and control of puberty. In: Control of the onset of puberty (Grumbach MM, Grave GD, Mayer F, eds), pp 403-423. Berlin: Springer.

Gargus JJ, Frace AM, Jung F (1993) The role of a PDGF-activated nonselective cation channel in the proliferative response. EXS 66:289-295.

Hamill OP, Marty A, Neher E, Sakmann B, Sigworth FJ (1981) Improved patch clamp techniques for high resolution current recording from cells and cell-free membrane patches. Pflügers Arch 391:85-100.

Hamill OP, Huguenard JR, Prince DA (1991) Patch-clamp studies of voltage-gated currents in identified neurons of the rat cerebral cortex. Cereb Cortex 1:48-61.

Haskins JT, Blankenship JE (1979) Interactions between bilateral clusters of neuroendocrine cells in Aplysia. J Neurophysiol 42:356-367.

Jones SM, Ribera AB (1994) Overexpression of a potassium channel gene perturbs neural differentiation. J Neurosci 14:2789-2799.

Kaczmarek LK, Strumwasser F (1984) A voltage-clamp analysis of currents underlying cyclic AMP-induced membrane modulation in isolated peptidergic neurons of Aplysia. J Neurophysiol 52:340-349.

Kaczmarek LK, Finbow M, Revel JP, Strumwasser F (1979) The morphology and coupling of Aplysia bag cells within the abdominal ganglion and in cell culture. J Neurobiol 10:535-550.

Kaczmarek LK, Jennings KR, Strumwasser F (1982) An early sodium and a late calcium phase in the afterdischarge of peptide-secreting neurons of Aplysia. Brain Res 238:105-115.

Kiehn O (1991) Plateau potentials and active integration in the "final common pathway" for motor behavior. Trends Neurosci 14:68-73.

Kupfermann I (1967) Stimulation of egg laying: possible neuroendocrine function of bag cells of abdominal ganglion of Aplysia californica. Nature 216:814-815. 
Kupfermann I, Kandel ER (1970) Electrophysiological properties and functional interconnections of two symmetrical neurosecretory clusters (bag cells) in abdominal ganglion of Aplysia. J Neurophysiol 33:865-876.

LeVay S, Wiesel TN, Hubel DH (1981) The postnatal development and plasticity of ocular-dominance columns in the monkey. In: The organization of the cerebral cortex (Schmitt FO, Worden FG, Adelman G, Dennis SG, eds), pp 29-45. Cambridge, MA: MIT.

Lima SL, Dill LM (1990) Behavioral decisions made under the risk of predation: a review and prospectus. Can J Zool 68:619-640.

Loechner KJ, Kaczmarek LK (1990) Control of potassium currents and cyclic AMP levels by autoactive neuropeptides in Aplysia neurons. Brain Res 532:1-6.

Loechner KJ, Kaczmarek LK (1994) Autoactive peptides act at three distinct receptors to depolarize the bag cell neurons of Aplysia. J Neurophysiol 71:195-203.

Mackey S, Carew TJ (1983) Locomotion in Aplysia: triggering by serotonin and modulation by bag cell extract. J Neurosci 3:1469-1477.

McAllister LB, Scheller RH, Brownell PH, Branton WD, Padgett L (1983) In situ hybridization to study the origin and fate of identified neurons. Science 222:800-808.

McCormick DA, Prince DA (1987) Post-natal development of electrophysiological properties of rat cerebral cortical pyramidal neurones. J Physiol (Lond) 393:743-762.

Meech RW (1974) The sensitivity of Helix aspersa neurones to injected calcium ions. J Physiol (Lond) 237:259-277.

Mills JD, Pitman RM (1995) A calcium-dependent potassium conductance determines electrical activity in an insect motoneurone. Soc Neurosci Abstr 33:11.

Nick TA, Kaczmarek LK, Carew TJ (1993) Mechanisms underlying the development of afterdischarge in the bag cell neurons of Aplysia. Soc Neurosci Abstr 708:7.

Nick TA, McKay SE, Kaczmarek LK, Carew TJ (1995) Outward currents of Aplysia bag cell neurons decrease with development of afterdischarge and with BDNF treatment. Soc Neurosci Abstr 223:1.
Nick TA, Moreira JE, Kaczmarek LK, Carew TJ, Wayne NL (1996) Developmental dissociation of excitability and secretory ability in Aplysia bag cell neurons. J Neurophysiol 76:5.

Pinsker HM, Dudek FE (1977) Bag cell control of egg-laying in freely behaving Aplysia. Science 197:490-493.

Ribera AB, Spitzer NC (1987) Both barium and calcium activate neuronal potassium currents. Proc Natl Acad Sci USA 84:6577-6581.

Ribera AB, Spitzer NC (1992) Developmental regulation of potassium channels and the impact on neuronal differentiation. In: Ion channels, Vol 3 (Narahashi T, ed), pp 1-38. New York: Plenum.

Rothman BS, Mayeri E, Brown RO, Yuan P-M, Shively JE (1983) Primary structure and neuronal effects of a-bag cell peptide, a second candidate neurotransmitter encoded by a single gene in bag cell neurons of Aplysia. Proc Natl Acad Sci USA 80:5753-5757.

Spitzer NC (1991) A developmental handshake: neuronal control of ionic currents and their control of neuronal differentiation. J Neurobiol 22:659-673.

Stearns SC (1976) Life-history tactics: a review of the ideas. Q Rev Biol $51: 3-47$.

Strong JA, Fox AP, Tsien RW, Kaczmarek LK (1987) Stimulation of protein kinase $\mathrm{C}$ recruits covert calcium channels in Aplysia bag cell neurons. Nature 325:714-717.

Stuart DK, Strumwasser F (1980) Neuronal sites of action of a neurosecretory peptide, egg-laying hormone in Aplysia californica. J Neurophysiol 43:499-519.

Turrigiano GG, Abbott LF, Marder E (1994) Activity changes in the intrinsic properties of cultured neurons. Science 264:974-976.

Turrigiano GG, LeMasson G, Marder E (1995) Selective regulation of current densities underlies spontaneous changes in the activity of cultured neurons. J Neurosci 15:3640-3562.

Wilson GF, Kaczmarek LK (1993) Mode-switching of a voltage-gated cation channel is mediated by a protein kinase A-regulated tyrosine phosphatase. Nature 366:433-438. 